\title{
ASYMMETRIC TRANSMISSION OF MONETARY POLICY TO INTEREST RATES: EMPIRICAL EVIDENCE FROM INDONESIA
}

\author{
Fitri Ami Handayani* and Febrio Kacaribu** \\ * Faculty of Economics and Business, University of Indonesia, Depok, Indonesia. Email:fitriami@pu.go.id \\ ** Corresponding Author. Faculty of Economics and Business, University of Indonesia, Depok, Indonesia. \\ Email:febrio.nathan@ui.ac.id
}

\begin{abstract}
This study investigates monetary policy transmission to the interest rates in Indonesia, focusing on changes in pricing behavior that may have occurred after the shift of benchmark policy rates in August 19, 2016. We analyzed monthly data on money market, deposit, and lending rates from November 2011 to December 2019. Two specifications of the error correction model capture asymmetric adjustments. We find that the new policy rate regime has improved the response of money market rates. However, the rigidity of bank retail rates has increased. Specifically, lending rates have become more rigid upwards, as lenders have become more responsive to monetary easing than to monetary tightening.
\end{abstract}

Keywords: Monetary policy; Asymmetric adjustment; Indonesia.

JEL Classifications: C22, E43, G21.

Article history:

Received : November 7, 2019

Revised : : August 20, 2020

Accepted : September 2, 2020

Available online : March 31, 2021

https://doi.org/10.21098/bemp.v24i1.1201 


\section{INTRODUCTION}

This paper investigates whether the transmission of monetary policy action to interest rates in Indonesia are incomplete or asymmetric. ${ }^{1}$ Under the Inflation Targeting Framework (ITF), the policy rate is the main instrument used to influence economic activity and to achieve the desired level of inflation (Juhro and Iyke, 2019a). ${ }^{2}$ From the interest rate channel ${ }^{3}$, amendments in the policy rates would affect the levels of bank deposit rates and lending rates (Warjiyo and Juhro, 2019). If possible, any change in the official rate needs to be passed through completely and symmetrically over a reasonably short time for the efficacy of monetary policy operations. ${ }^{4}$ When the pass-through (from input to output prices) is asymmetric, it may signal different distribution of welfare between players in the market than it would under symmetric circumstances (Peltzman, 2000). Moreover, from the perspective of policy makers, the impact of monetary policy to the economy may differ between tightening and expansionary policy action (Chong et al., 2006; Zulkhibri, 2012).

To be more specific, we examine whether there are any short- and longrun changes to the interest rate pass-through, following Bank Indonesia's (BI's) introduction of the seven-day reverse repo rate (7DRR $)^{5}$ to replace the Bank Indonesia Certificate (also known as the BI rate), as the new benchmark policy rate in August 2016. ${ }^{6}$ The reason behind the switch from the benchmark policy rate is to accelerate the transmission of the policy rate to the money market, banking industry, and the real sector (Warjiyo and Juhro, 2019).

In order to boost economic growth, the BI has aggressively cut its policy rates in the past few years (Pontines and Siregar, 2017). As the policy rates reduce, the lending rates are expected to reduce as well, which will, in turn, stimulate consumption and investment (Warjiyo and Juhro, 2019). Despite these policy rate cuts, the impact of monetary policy was not completely passed on to lending and

1 This has become more relevant given the disruption of the domestic and external markets caused by the COVID-19 outbreak (Devpura and Narayan, 2020; Haroon and Rizvi, 2020; Iyke, 2020a, 2020b; Mishra et al., 2020; Phan and Narayan, 2020; Prabheesh et al., 2020; Vidya and Prabheesh, 2020). Understanding the transmission of monetary policy will help policymakers to better design effective policies to steer the economy out of the current domestic and global uncertainty.

2 Indonesia's ITF has been in existence since 2005 (see Juhro and Iyke, 2019b). In this ITF regime, monetary policy prioritized the interest rate as its operational target using policy interest rate setting. The policy signal would be transmitted through various channels, such as the lending and expectation channels (see Juhro and Iyke, 2020), to influence domestic demand and inflation. Monetary operations are regularly improved to boost policy effectiveness, especially in terms of maintaining price stability (see Juhro and Iyke, 2019b).

3 The other channel of monetary policy consists of expectation, exchange rate, monetary and credit channels (see Juhro and Iyke, 2020).

4 Hofmann and Mizen (2004) suggested that a complete or one-to-one pass-through will strengthen the ability of monetary policy to control inflation. In addition, Lim (2001) argue that if monetary policy is to be influential to aggregate demand and the real economy, the magnitude of the official rate changes that is passed through to commercial interest rates should be large enough.

5 The new BI 7-Day (Reverse) Repo Rate has a stronger correlation with money market rates, is transactional or tradeable on the market and increases financial market deepening (Warjiyo and Juhro, 2019).

6 Even though the BI rate is around 150 basis points higher than the 7DRR rate, the two rates have the same term structure. Thus, this does not imply an expansionary monetary policy (see Juhro and Iyke, 2019a). 
deposit rates. For example, the monetary policy tightening in the second half of 2013 was passed on to deposit and lending rates to varying degrees (see Bank Indonesia, 2014). As the policy rate increased by 175 basis points (bps), the deposit rate increased by 168 bps (or by $96 \%$ of the policy rate rise). ${ }^{7}$ In the meantime, the average lending rate ascended by only 41 bps (or by $23 \%$ of the policy rate rise) ${ }^{8}$ In reverse, the banks transmitted $93 \%$ of the reduction in the policy rate ${ }^{9}$ to the deposit rate, as the BI eased monetary policy throughout December 2015 to November 2017. However, banks only passed on $69 \%$ of the policy rate cuts to the lending rates. ${ }^{10}$ These reflect the varying response of the interest rates to monetary policy changes. First, the lending rates appear to be stickier than the deposit rates. Second, lenders pass on the monetary policy easing to borrowers to a greater extent than the monetary policy tightening.

Among the empirical studies that analyze the asymmetric interest rate passthrough, some have confirmed the asymmetric adjustment in lending rates that favor lenders in the US, the UK, Europe, and Australia (Payne, 2006; Becker et al., 2012; Toolsema and Jacobs, 2007; Cecchin, 2011; Sjölander, 2013; Sjölander et al., 2015; Valadkhani and Anwar, 2012; Valadkhani and Worthington, 2014). ${ }^{11}$ Other studies, especially those focusing on Asian countries, such as Singapore, Malaysia, Taiwan, and Hong Kong and those on South Africa, found the opposite result (Chong et al., 2006; Zulkhibri, 2012; Wang and Thi, 2010). In other words, they found that interest rates adjust downward faster to policy rate cuts than upward to policy rate increases, confirming the heterogeneity in the interest rate pass-through mechanism. To summarize, prior studies show that interest rate pass-through is incomplete and sluggish, and that the lending rates adjust asymmetrically to monetary policy changes in many countries. Table 1 summarizes the literature in terms of the two clusters. The first cluster recognizes that lenders have the advantage, since they respond to policy rate increases strongly than to cuts, resulting in downward rigidity of the interest rates. The second cluster suggests the opposite: that the asymmetric adjustment favors borrowers, since the lending rates respond more strongly to rate cuts than to rate hikes. Interestingly, there are conflicting results in some countries.

7 This is discussed in "Monetary Policy Review: Economy, Monetary, and Finance" by BI on January 2014 and is accessible at https://www.bi.go.id/en/publikasi/kebijakan-moneter/tinjauan/Pages/ Monetary-Policy-Review-January-2014.aspx.

8 This is discussed in "Monetary Policy Review: Economy, Monetary, and Finance" by BI on January 2014 and is accessible at https:/www.bi.go.id/en/publikasi/kebijakan-moneter/tinjauan/Pages/ Monetary-Policy-Review-January-2014.aspx.

9 During monetary policy easing, from December 2015 to November 2017, the policy rate dropped by a total of 200 bps.

10 See "Monetary Policy Review: Economy, Monetary, and Finance" of January 2018, which is available on BI's website at https://www.bi.go.id/en/publikasi/kebijakan-moneter/tinjauan/Pages/TinjauanKebijakan-Moneter-Bulan-Januari-2018.aspx. It also reported that the reductions in interest rates on consumer (i.e., household) loans were the main contributor to the lower lending rates than the investment loans and working capital loans.

${ }^{11}$ Lenders are in a position to generate large profits at the expense of their customers in the event that interest rates adjust upward faster and/or larger (in response to a policy rate rise) than downward (in response to a policy rate drop). Consequently, customers are not gaining from any interest rate reduction as they would under conditions of symmetry (Apergis and Cooray, 2015). 
Table 1.

\section{Summary of Asymmetric Adjustments from Related Studies}

This table presents the various type of adjustment asymmetry from the empirical studies in many countries, which can be clustered into two groups. The first group is the downward rigidity, and the second group is the upward rigidity of the interest rates.

\begin{tabular}{|c|c|c|c|}
\hline Country & Benchmark Rate & Interest Rate & Study \\
\hline \multicolumn{4}{|c|}{ Panel A: Downward Rigidity } \\
\hline US & $\begin{array}{l}\text { Federal Funds } \\
\text { Rate }\end{array}$ & Fixed Mortgage Rate & Payne (2006) \\
\hline UK & Interbank & $\begin{array}{c}\text { Standard Variable Mortgage } \\
\text { Rates }\end{array}$ & Becker et al. (2012) \\
\hline Netherlands & $\begin{array}{l}\text { Capital Market } \\
\text { Rate }\end{array}$ & Average Mortgage Rate & Toolsema and Jacobs (2007) \\
\hline Australia & Policy Rate & Mortgage Rate & $\begin{array}{l}\text { Valadkhani and Anwar (2012); } \\
\text { Valadkhani and Worthington } \\
\text { (2014). }\end{array}$ \\
\hline Switzerland & Swap Rate & Fixed Rate Mortgage Rate & Cecchin (2011) \\
\hline Hong Kong & $\begin{array}{l}\text { Money Market } \\
\text { Rate }\end{array}$ & Lending Rate & \\
\hline Korea & $\begin{array}{c}\text { Money Market } \\
\text { Rate }\end{array}$ & Lending Rate & Yu et al. (2013) \\
\hline \multicolumn{4}{|c|}{ Panel B: Upward Rigidity } \\
\hline US & $\begin{array}{l}\text { Federal Funds } \\
\text { Rate }\end{array}$ & Adjustable Mortgage Rate & Payne (2007) \\
\hline Australia & $\begin{array}{l}\text { Swap Rate } \\
\text { Deposit Rate }\end{array}$ & $\begin{array}{l}\text { Average Mortgage Rates } \\
\text { Lending Rates }\end{array}$ & Liu et al. (2016) \\
\hline New Zealand & Banks Bill Rate & $\begin{array}{l}\text { Average First Home-owner } \\
\text { Mortgage Rate }\end{array}$ & Frost and Bowden (1999) \\
\hline Singapore & Interbank Rates & $\begin{array}{l}\text { Lending Rate } \\
\text { Deposit Rate } \\
\text { Saving Rate }\end{array}$ & Chong et al. (2006) \\
\hline Malaysia & Interbank Rates & $\begin{array}{l}\text { Lending Rates } \\
\text { Deposit Rates }\end{array}$ & Zulkhibri (2012) \\
\hline Taiwan & Call Loan Rate & $\begin{array}{l}\text { Lending Rates } \\
\text { Deposit Rates }\end{array}$ & Wang and Thi (2010) \\
\hline South Africa & $\begin{array}{l}\text { Money Market } \\
\text { Rate }\end{array}$ & Base Lending Rate & Matemilola et al. (2014) \\
\hline Indonesia & Call Money Rates & Working Capital Loan Rate & \\
\hline Thailand & $\begin{array}{l}\text { Money Market } \\
\text { Rate }\end{array}$ & Lending Rate & Yu et al. (2013) \\
\hline Netherlands & Swap Rate & Individual Mortgage Rate & Haan and Sterken (2011) \\
\hline
\end{tabular}

However, prior studies on interest rate pass-through in Indonesia have assumed asymmetric adjustment process. They have validated that the transmission from monetary policy to the commercial interest rates is sluggish and incomplete (Tai et al., 2012; Falianty and Listiyanto, 2013; Wibowo and Lazuardi, 2016; Pontines and Siregar, 2017). To the best of our knowledge, only Yu et al. (2013) have examined the potential asymmetric interest rate pass-through in the short- and long-run in Indonesia. They studied the relationship between interbank call money rates and 
investment loan rates in Indonesia and found evidence of a long-run asymmetric transmission, even though the speed of adjustment is symmetric.

Against this background, we contribute to the literature by showing new evidence of asymmetric pass-through in the money market and retail bank interest rates (i.e. the deposit and lending rates). We also investigate the effect of the new benchmark policy rate on the degree of interest rate pass-through. Unlike the majority of prior studies using the Thresshold AutoRegressive (TAR) procedure (see, for example, Enders and Siklos, 2001; Payne, 2007; Liu et al., 2008; Chong, 2010), we adopt the 3-ECT specification utilized by Valadkhani and Worthington (2014). Although the TAR model could sufficiently address the issues of asymmetric adjustment to positive and negative deviations from the long-run equilibrium path, it fails to take into account the varying responses of banks to small and large deviations as predicted by Hofmann and Mizen (2004). Thus, the 3-ECT model allows possible different adjustments between small and large deviations from the long-run equilibrium path, which is the focus of our study. ${ }^{12}$ In addition, we investigate various consumer loans rate, which are considered less sensitive to monetary policy shifts (Gregor et al., 2019). Moreover, we take into consideration the different degrees of monetary policy transmission between the two regimes of benchmark policy rates, namely the BI rate regime (from November 2011 to August 2016) and the 7DRR regime (from September 2016 to December 2019).

Based on a historical monthly dataset covering the period November 2011 to December 2019, we show that monetary policy has varying impacts on different groups of interest rates. The policy rate changes have been completely passed on to the money market rate. However, banks adjust their deposit and lending rates incompletely and sluggishly. The lending rates are found to be less sensitive, as the markup is higher and the degree of pass-through is smaller in the long run. There is also evidence that the markup has increased during the new policy rate regime, while the pass-through has declined. Furthermore, the short-run analysis reveals that the adjustments of the interest rates are mostly symmetric. However, there is a structural change to the adjustment speed when the disequilibrium is large and negative. This indicates that the working capital loan, investment loan, and mortgage rates are only responsive to a relatively large decrease in the policy rate. Thus, most lending rates are more sensitive to monetary tightening than to monetary easing. As the actual lending rates were distinctly higher than the market equilibrium, these lenders briefly lowered their rates. This type of asymmetry leads to upward rigidity of the interest rates, consistent with previous studies on Indonesia (Yu et al., 2013) and other Asian countries (Chong et al., 2006; Wang and Thi, 2010, Tai et al., 2012; Zulkhibri, 2012;). Tai et al. (2012) argued that this condition has to do with the imperfect financial markets and the low financial integration in these economies. Finally, we also confirmed that, amongst the lending rates, the consumer loan rates are the most rigid. Thus, the monetary authorities should not expect to influence the pricing of consumer loans as effectively as other segments of the loans market.

\footnotetext{
${ }^{12}$ Our approach is unlike Sjölander (2013), who used the new asymmetric interaction ridge regression method developed by Månsson et.al (2013) or Sjölander et al. (2015), who implemented a Wavelet quantile regression.
} 
The remainder of the paper is organized as follows. Section II describes our model and data. Section III presents and discusses the results. Section IV concludes the paper.

\section{METHODOLOGY}

A. Econometric Approach

In order to capture both long- and short-run dynamics of the interest rate passthrough, we follow previous studies, such as Chong (2010) and Liu et al. (2016), and employ the two-step Error-Correction Model (ECM). The interest rate-setting behaviour follows marginal cost pricing model by Rousseas (1985), where the bank interest rate is subject to cost of funds and constant markup (intermediation margin). We also assumed, following Becker et al. (2012), that the policy rate set by the $\mathrm{BI}$ is weakly exogenous to the market rate and the bank's interest rate. ${ }^{13}$

\section{B. Symmetric Long-Run Analysis}

The first step of ECM examines the long-run relationship between the interest rates as follows:

$$
L R_{t}=\alpha_{0}+\alpha_{1} B R_{t}+\alpha_{2} D+\alpha_{3} D * B R_{t}+\varepsilon_{t}
$$

where $\alpha_{0}$ denotes the constant intermediation margin, which consists of mark-up and marginal cost; $\alpha_{1}$ is the size of long-run pass-through; $t$ denotes time; and $\varepsilon_{t}$ denotes the error term. The variable $L R_{t}$ indicates the interest rate ${ }^{14}$ while $B R$ represents the policy rate. As the loan spread and the relationship between lending rate and policy rate or market rate are typically positive, we expect that $\alpha_{0}>0$ and $\alpha_{1}>0 .{ }^{15}$

$D$ is the new benchmark policy rate dummy variable, which is equal to 1 after the introduction of 7DRR as the policy rate in August 2016 and 0 otherwise. We include the new benchmark rate dummy variable to capture the structural change in the long-run relationship between monetary policy and the interest rates after the shift of the benchmark policy rate. Thus, the coefficient $\alpha_{2}$ measures the change in the intermediation margin, while $\alpha_{3}$ captures the structural changes in the magnitude of long-run pass-through following the introduction of the new benchmark policy rate.

We test the unit root properties of the residual obtained from Equation (1) for cointegration (Valadkhani and Anwar, 2012). Afterward, to examine the possibility

\footnotetext{
${ }^{13}$ Some studies also explored the influence of domestic factors, such as growth, financial market development, volatility of market rates, and inflation, on the interest rate pass-through (Andries and Billon, 2016). On the other hand, Pontines and Siregar (2017) assumed that favorable global financial conditions have contributed to the rise of funding through "non-core" liabilities in the Indonesian domestic banks. They argued that this may affect the transmission of monetary policy to bank interest rates.

${ }^{14}$ The money market rate, bank deposit rate and bank lending rate.

${ }^{15}$ Iyke $(2017 \mathrm{a}, \mathrm{b})$ used the same intuition to fit the relationship between the policy rate and the yield on long-term government bonds/treasury bill rate.
} 
of a complete pass-through, we applied the Wald test to the coefficients of longrun pass-through. That is, we test the hypotheses Ho: $\alpha_{1}=1$ against $H_{0}: \alpha_{1} \neq 1$ for the old policy rate regime, and Ho: $\alpha_{1}+\alpha_{3}=1$ against $H o: \alpha_{1}+\alpha_{3} \neq 1$ for the new policy rate regime.

\section{Asymmetric Short-Run Analysis Using the TAR Model}

In the second step of the ECM analysis, we analyze the short- and long-run dynamics of the interest rate pass-through, focusing on the immediate pass-through and the speed of adjustment. The estimated residual term obtained from long-run equation is used as a proxy for measuring the magnitude of the disequilibrium. We estimate the short-run dynamics using the Threshold AutoRegressive (TAR) model that captures positive and negative adjustments as follows:

$$
\Delta L R=\varphi_{1} \Delta B R_{t}+\varphi_{2}^{+} \hat{\varepsilon}_{t-1}^{+}+\varphi_{2}^{-} \hat{\varepsilon}_{t-1}^{-}+\varphi_{3} D * \Delta B R_{t}+\varphi_{4}^{+} D * \hat{\varepsilon}_{t-1}^{+}+\varphi_{4}^{-} D * \hat{\varepsilon}_{t-1}^{-}+v_{t}
$$

where $\Delta$ is the first difference operator; $v_{t}, u_{t}$, and $w_{t}$ are the error terms, $\hat{\varepsilon}_{t-1}^{+}$and $\hat{\varepsilon}_{t-1}^{-}$are the residuals of the long-run model (Equation (1)), which represents the deviation of interest rate from long-run equilibrium at time $t-1$. Chong (2010) used the TAR model to study the asymmetric adjustment of retail bank interest rates to changes in benchmark rate (policy rate or money market rate). In this model, coefficient $\varphi_{1}{ }^{+}$captures the degree of direct pass-through. The coefficients $\varphi_{2}{ }^{+}$and $\varphi_{2}^{-}$capture the speeds of adjustment asymmetry under positive and negative disequilibria conditions, respectively. The variables $\hat{\varepsilon}_{t-1}^{+}$and $\hat{\varepsilon}_{t-1}^{-}$are defined as:

$$
\begin{aligned}
& \hat{\varepsilon}_{t-1}^{+}=\hat{\varepsilon}_{t-1} \text { if } \hat{\varepsilon}_{t-1}>0 \text { and } \hat{\varepsilon}_{t-1}^{+}=0 \text { otherwise } \\
& \hat{\varepsilon}_{t-1}^{-}=\hat{\varepsilon}_{t-1} \text { if } \hat{\varepsilon}_{t-1}<0 \text { and } \hat{\varepsilon}_{t-1}^{-}=0 \text { otherwise }
\end{aligned}
$$

The new benchmark rate dummy is also included in Equation (2) to capture the structural change in the short-run relationship between the interest rates following the introduction of the new policy rate. The coefficient $\varphi_{3}$ captures the change in the magnitude of direct pass-through, while $\varphi_{4}{ }^{+}$and $\varphi_{4}^{-}$measure the change in the error-correction adjustment speed when the interest rates are above and below the equilibrium level, respectively.

\section{Asymmetric Short-Run Analysis using 3-ECT Model}

We do not only inspect the directions of the asymmetric adjustment, but also the different responses of the banks to small and large deviations. We follow Valadkhani and Worthington (2014), and extend the TAR model by incorporating three error correction terms as follows:

$$
\begin{aligned}
\Delta L R= & \varphi_{5} \Delta B R_{t}+\varphi_{6}^{L+} \hat{\varepsilon}_{t-1}^{L+}+\varphi_{6}^{L-} \hat{\varepsilon}_{t-1}^{L-}+\varphi_{6}^{S} \hat{\varepsilon}_{t-1}^{S}+\varphi_{7} D * \Delta B R_{t}+\varphi_{8}^{L+} D * \hat{\varepsilon}_{t-1}^{L+}+ \\
& \varphi_{8}^{L-} D * \hat{\varepsilon}_{t-1}^{-}+\varphi_{8}^{S} D * \hat{\varepsilon}_{t-1}^{S}+w_{t}
\end{aligned}
$$


In this model, we decompose the residual term from the long-run equation (Equation (1)) into three sub-series of almost equal length based on the standardized $z$-scores of a normal distribution. ${ }^{16}$ Thus, the variables $\hat{\varepsilon}_{t-1}^{L+}, \hat{\varepsilon}_{t-1}^{L-}$, and $\hat{\varepsilon}_{t-1}^{S}$ are defined as:

$$
\begin{aligned}
& \hat{\varepsilon}_{t-1}^{L+}=\hat{\varepsilon}_{t-1} \text { if } \hat{\varepsilon}_{t-1} \geq 0.44 \hat{\sigma} \text { and } \hat{\varepsilon}_{t-1}^{L+}=0 \text { otherwise } \\
& \hat{\varepsilon}_{t-1}^{L-}=\hat{\varepsilon}_{t-1} \text { if } \hat{\varepsilon}_{t-1} \leq-0.44 \hat{\sigma} \text { and } \hat{\varepsilon}_{t-1}^{L-}=0 \text { otherwise } \\
& \hat{\varepsilon}_{t-1}^{S}=\hat{\varepsilon}_{t-1} \text { if }-0.44 \hat{\sigma}<\hat{\varepsilon}_{t-1}<0.44 \hat{\sigma} \text { and } \hat{\varepsilon}_{t-1}^{S}=0 \text { otherwise }
\end{aligned}
$$

where $\hat{\sigma}$ is the estimated standard deviation of $\hat{\varepsilon}_{t^{\prime}}$ whereby $\varepsilon_{t} \sim N I D(0, \hat{\sigma})$.

Comparable to the TAR model (Equation (2)), the coefficient $\varphi_{5}$ captures the degree of short-term pass-through of positive and negative changes of the policy rate. However, there are three dissimilar coefficients allowing us to capture the varying speeds of adjustment. The coefficients $\varphi_{6}^{L+}, \varphi_{6}^{L-}$ and $\varphi_{6}^{S}$ are the speeds of adjustment when the disequilibria are assumed to be positive and large, negative and large, and small, respectively. Similar to Equations (1) and (2), we also incorporate the new benchmark policy rate dummy in Equation (3). The structural change to the degree of short-run pass through is captured by $\varphi_{7}$. Thus, the structural changes to the adjustment speed when the disequilibria are assumed to be positive and large, negative and large, and small are captured by $\varphi_{6}^{L+}, \varphi_{6}^{L-}$, and $\varphi_{6}^{S}$, respectively. All coefficients for the speed of adjustments in all models (i.e., $\varphi_{2}^{+}$, $\varphi_{2}^{-}, \varphi_{6}^{L+}, \varphi_{6}^{L-}$, and $\left.\varphi_{6}^{S}\right)$ are expected to be negative as a correcting mechanism into the long-run equilibrium.

\section{E. Wald Tests}

We also examine the existence of interest-rate convergence by using the Wald test. The null hypothesis and alternative hypothesis for each model is as follows: $H_{0}: \varphi_{4}^{L+}=\varphi_{4}^{L-}=0$ against $H_{1}: \varphi_{4}^{L+} \neq \varphi_{4}^{L-} \neq 0$ for Equation (2), and $H_{0}: \varphi_{4}^{L+}=\varphi_{4}^{L-}=\varphi_{4}^{S}=0$ against $H_{1}: \varphi_{6}^{L+} \neq \varphi_{6}^{L-} \neq \varphi_{6}^{S} \neq 0$ for Equation (3). In addition, the significance of the above feedback coefficients, which is examined by using the critical values, might also verify the existence of cointegration between policy rate and interest rates (Kremers et al., 1992; Boswijk, 1994; de Bondt, 2005).

After that, we execute other Wald tests to inspect adjustment asymmetry. First, we investigate the asymmetric speeds of adjustment by using the following null hypotheses: $H_{0}: \varphi_{2}^{L+}=\varphi_{2}^{L-}$ in Equation (2) and $H_{0}: \varphi_{6}^{L+}=\varphi_{6}^{L-}=\varphi_{6}^{S}$ in Equation (3) for the period of the old benchmark policy rate. Second, we test the asymmetric adjustment after the switch of benchmark policy rate under $H_{0}: \varphi_{2}^{L+}+\varphi_{4}^{L+}=\varphi_{2}^{L-}+\varphi_{4}^{L-}$ in Equation (2) and $H_{0}: \varphi_{6}^{L+}+\varphi_{8}^{L+}=\varphi_{6}^{L-}+\varphi_{8}^{L-}=\varphi_{6}^{S}+\varphi_{8}^{S}$ in Equation (3).

\footnotetext{
${ }_{16}$ The area between $z=-0.44$ and $z=+0.44$ is approximately equal to 33 percent of the total area under the normal distribution. Similarly, the area corresponding to $z \geq-0.44$ (or $z<-0.44$ ) represents one-third of the total area (Valadkhani and Worthington, 2014).
} 


\section{F. Data}

We analyze monetary policy transmission to four groups of interest rates, which are: (1) money market rates; (2) time deposit and saving rates; (3) aggregate lending rates; and (4) consumer loans rates. The sample covers the period from October 2011 to December 2019. We obtain the monthly data on money market, deposit, and saving rates from the BI database of Indonesian Financial Statistics (Bank Indonesia, 2020) and the consumer loan rates from the Indonesia Financial Service Authority's (OJK's) database and the Indonesian Banking Statistics (Indonesian Financial Services Authority, 2020). In order to investigate the potentially different transmissions of monetary policy between the two regimes of the benchmark official rates, we used the Deposit Facility ${ }^{17}(\mathrm{DF})$ rate as a representation of the policy rates. Figure 2 presents the relationship between the DF rate and the benchmark policy rates. It shows that the DF rate adjusts one-to-one to the movement of both the BI and 7DRR rates.

We used the Overnight Jakarta InterBank Offered Rate (JIBOR) ${ }^{18}$ as a proxy for short-term money market rate along with the interbank call money rates following Yu et al. (2013). Additionally, we used the one- and three-month JIBOR (J1M and $\mathrm{J} 3 \mathrm{M}$, respectively) as proxies for long-term money market rates. There are five maturities of time deposit, namely one month (D1M), three months (D3M), six months (D6M), one year (D1Y), and up to two years (D2Y). The aggregate lending rates consist of working capital loans, consumer loans and investment loans. Specifically, we also investigate three categories of consumer loan products, which consist of mortgage (i.e. non-residential mortgage (MNR), residential mortgage for apartment (MRA), and residential mortgage for housing), vehicle loans (VHC), and others consumer credit (OTH). ${ }^{19}$

\section{EMPIRICAL RESULT}

A. Graphical Analysis

Our sample period covers the changes in policy rate as can be seen in Figure 1. The market rates with shorter maturity (i.e. interbank call money and overnight JIBOR) appear to move very closely with the DF rate. However, the gap between policy rate and the longer maturity of JIBOR (J1M and J3M) has been widening since 2013. Similarly, the gap between the DF rate and deposit rates widened between 2013 to 2016, but narrowed after 2016.

\footnotetext{
${ }_{17}$ Deposit Facility (DF) is the rupiah fund placement activities by banks with the Bank Indonesia in terms of monetary operation within a period of one working day (Bank Indonesia, 2020).

18 The JIBOR is the average of unsecured lending indicative interest rate, which is offered and aimed for transactions by a contributor bank to another for rupiah lending in Indonesia for a tenor longer than overnight (Bank Indonesia, 2020).

19 These include credit card, multi-purposes personal loans, furniture loans, and electronic loans.
} 
Figure 1.

\section{Interest Rates}

This figure shows the movements of the interest rates. The first group (first row, left) is the policy rate and the Deposit Facility rate. The second group (first row, right) is the money market rates. The third group (second row, left) is the deposit rates. The fourth group (second roe, right) is the lending rates. And the last group (third row) is the consumer loans rate). J1N, J1M, J3M, ICM, D1M, D3M, D6M, D1Y, D2Y, CAP, INV, CONS, MNR, MRA, MRH, OTH and VEH denote Deposit Facility Rate, JIBOR Overnight Rate, JIBOR 1-Month Rate, JIBOR 3-Month Rate, Interbank Call Money Rate, Deposit 1-Month Rate, Deposit 3-Month Rate, Deposit 6-Month Rate, Deposit 1-Year Rate, Deposit 2-Year Rate, Working Capital Loan Rate, Investment Loan Rate, Consumer Loan Rate, Non-Residential Mortgage Rate, Apartment Mortgage Rate, Housing Mortgage Rate, Other Loan Rate, and Vehicle Loan Rate, respectively.
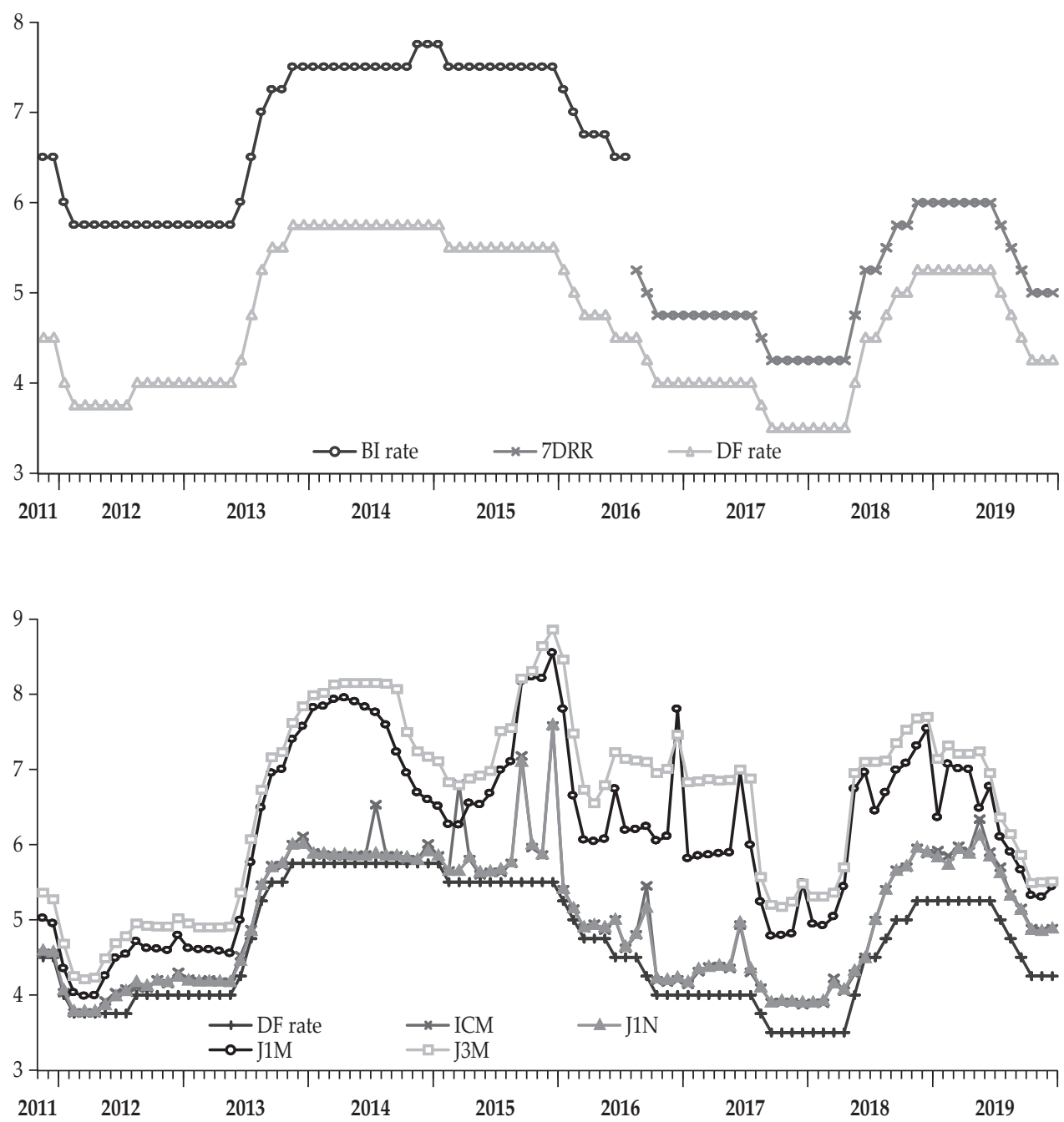
Figure 1.

Interest Rates (Continued)
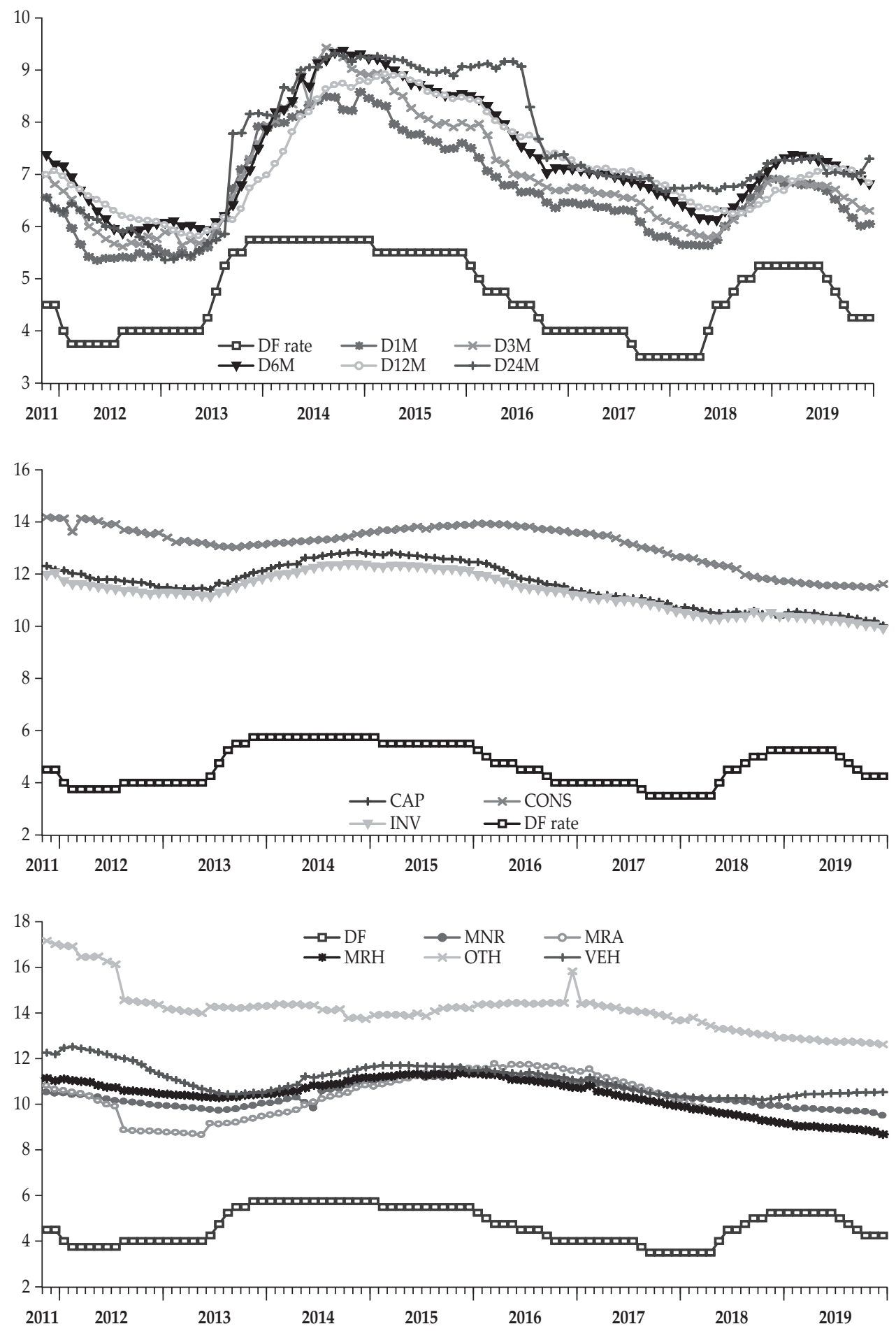
Although the lending rates are trailing the policy rate until the end of 2017, we observe some indications of incomplete and asymmetric pass-through. For example, as the DF rate showed an upward trend (i.e. it increased by total $150 \mathrm{bps}$ ) during the contractionary monetary policy period (in second half of 2013), the increase in the lending rate is not of the same magnitude. The increase in working capital and investment loan rates are only around $65 \mathrm{bps}$ (44\% of total policy rates rise), narrowing the gap between these rates. In addition, consumer loans do not appear to be responsive to the monetary policy rate since they show no obvious change during that period. Thus, we remark that these lending rates appear to adjust incompletely and sluggishly to changes in the monetary policy. In reverse, when the policy rate was on a downward trajectory following BI's introduction of monetary policy easing from January to October 2016, the lending rate showed a larger magnitude decline. Working capital loans reacted the most (by 87 bps, or $58 \%$ ), followed by investment loans (by 78 bps, or 52\%) and consumer loans (by 20 bps, or 13\%). We can clearly see that consumer loans rates were the most rigid as they altered slightly and slowly following the change in the policy rate. We also visualize the behavior of the interest rates under the 7DRR regime and observe that the lending rates do not react to both monetary policy easing in 2018 and 2019. Thus, we argue that the lending rates became stickier since 2016.

\section{B. Correlation Analysis}

The pair-wise correlation coefficients between the policy rate and the interest rates are reported in Table 2 . The correlation analysis yields some notable findings. First, consistent with the result of Chong et al. (2006) and Zulkhibri (2012), the deposit rates are, on average, more highly correlated to the policy rate than the lending rates. Second, a comparison of the pair-wise correlation for the BI rate and 7DRR regimes reveals that the level of correlation between the policy rate and most of the interest rates has been falling, except for the short-term money market rates. The drop in the degree of correlation to lending rates of the policy rate is higher, ranging from $100-150 \%{ }^{20}$, while the degree of correlation to deposit rates of the policy rate ranges from $17 \%$ to $126 \%$. On the other hand, the degree of correlation to long term money market rates of the policy rate has fallen by between $20 \%$ to $24 \%$, and the correlation to short term money market rates of the policy rate has risen by $4 \%$. This result suggests that most of the interest rates are more responsive to the $\mathrm{BI}$ rate than to 7DDR.

\section{Unit Root Tests}

We follow Payne (2007) and test whether the interest rates have unit roots (i.e. whether they are I[0] or I[1] series). Table 3 shows the results, which are based on three conventional unit root tests, namely the Augmented Dickey-Fuller (ADF), the Phillips-Perron (PP), and the Kwiatkowski-Phillips-Schmidt-Shin (KPSS) unit root tests. The results suggest that all the interest rates are I[1] series or

${ }^{20}$ These are the declines in the correlation between the policy rate and the aggregate lending rates. In addition, the decrease in correlation between the policy rate and the consumer loan products ranged from $8 \%$ to $330 \%$. 
contain unit roots. ${ }^{21}$ Hence, we proceed with the remaining analysis given that the variables have unit roots.

Table 2.

\section{Correlation Analysis}

This table presents the correlation coefficient matrix between variables. Column 1 presents the interest rates. J1N, J1M, J3M, ICM, D1M, D3M, D6M, D1Y, D2Y, CAP, INV, CONS, MNR, MRA, MRH, OTH and VEH denote Deposit Facility Rate, JIBOR Overnight Rate, JIBOR 1-Month Rate, JIBOR 3-Month Rate, Interbank Call Money Rate, Deposit 1-Month Rate, Deposit 3-Month Rate, Deposit 6-Month Rate, Deposit 1-Year Rate, Deposit 2-Year Rate, Working Capital Loan Rate, Investment Loan Rate, Consumer Loan Rate, Non-Residential Mortgage Rate, Apartment Mortgage Rate, Housing Mortgage Rate, Other Loan Rate, and Vehicle Loan Rate, respectively. Column 2 presents the correlation between policy rate and the interest rates during the BI rate regime. Column 3 presents the correlation between policy rate and the interest rates during the 7DRR regime. Column 4 presents the increase or decrease of correlation between the benchmark rates period.

\begin{tabular}{lccc}
\hline Interest Rates & BI rate regime & 7DRR regime & Change \\
\hline $\mathbf{1}$ & $\mathbf{2}$ & $\mathbf{3}$ & $\mathbf{4}$ \\
\hline Observation & $\mathbf{5 8}$ & $\mathbf{4 0}$ & \\
\hline \multicolumn{4}{c}{ Panel A: Money Market Rates } \\
\hline J1N & 0.931 & 0.969 & 0.039 \\
J1M & 0.918 & 0.733 & -0.186 \\
J3M & 0.915 & 0.688 & -0.227 \\
ICM & 0.920 & 0.961 & 0.041 \\
\hline \multicolumn{4}{c}{ Panel B: Deposit and Saving Rates } \\
\hline D1M & 0.941 & 0.780 & -0.161 \\
D3M & 0.878 & 0.515 & -0.363 \\
D6M & 0.814 & 0.479 & -0.335 \\
D12M & 0.710 & -0.185 & -0.895 \\
D24M & 0.818 & 0.424 & -0.394 \\
\hline \multicolumn{4}{c}{ Panel C: Lending Rates } \\
\hline CAP & 0.792 & -0.474 & -1.265 \\
CONS & -0.330 & -0.669 & -0.339 \\
INV & 0.807 & -1.224 \\
\hline \multicolumn{4}{c}{-0.417} \\
\hline MNR & Panel D: Consumer Loans Rates \\
MRA & 0.338 & -0.573 \\
MRH & 0.326 & -0.611 & -0.911 \\
OTH & 0.267 & -0.623 & -0.937 \\
VEH & -0.578 & -0.625 & -0.890 \\
\hline & -0.407 & -0.257 & 0.150 \\
\hline
\end{tabular}

\section{Long Run Pass-through}

First, we estimate the long-run relationship between interest rates using Equation (1) and these results are presented in Table 4. Consistent with Zulkhibri (2012), the markup for lending rates (Panels $C$ and $D$ ) are much higher than for deposit rates

${ }^{21}$ All tests consistently show that DF, J1N, J1M, J3M, D1M, D3M, D2Y, INV, and MNR rates are integrated of order one or are I[1]. The ADF unit root test suggests that the ICM, MRA, and OTH rates are $\mathrm{I}(0)$, while the PP and KPSS unit root tests indicate that these rates are I(1). The PP and KPSS unit root tests also indicate that D6M, D1Y, CAP, CONS, and MRH rates are I(1). Finally, the ADF unit root test results suggest that VEH is I(0), while the PP unit root test suggest that it is I(1). 
Table 3.

\section{Unit Root Tests}

This table shows the unit root test of the variables based on Augmented Dickey-Fuller (ADF), Phillips-Perron (PPP) and Kwiatkowski-Phillips-Schmidt-Shin (KPSS). The null hypothesis for ADF and PP tests are series contain unit root (non-stationary). The test statistic of ADF and PP are compared with critical values tabulated by MacKinnon (1994) and MacKinnon (1996), respectively. Lags are selected automatically using Schwarz Information Criterion (SBC). The null hypothesis for KPSS test is series contains no unit root (stationary). The test statistic of KPSS is compared with critical values from Kwiatkowski et al. (1992). Bandwidths are chosen according to Newey-West using Bartlett kernel, where, ${ }^{*}, * *$ and ${ }^{* * *}$ denote rejection of unit root at $10 \%, 5 \%$, and $1 \%$, respectively. The sample period used is from January 2011 to December 2017. All variables are as described in earlier tables - see table 2 for instance.

\begin{tabular}{|c|c|c|c|c|c|c|c|c|c|c|}
\hline \multirow[b]{2}{*}{ Variables } & \multicolumn{4}{|c|}{ ADF } & \multicolumn{3}{|c|}{ PP } & \multicolumn{3}{|c|}{ KPSS } \\
\hline & Levels & & $\begin{array}{c}\text { First } \\
\text { Difference }\end{array}$ & & Levels & $\begin{array}{c}\text { First } \\
\text { Difference }\end{array}$ & & Levels & & $\begin{array}{c}\text { First } \\
\text { Difference }\end{array}$ \\
\hline \multicolumn{11}{|c|}{ Panel A: Official Rates } \\
\hline DF & -1.52 & & -5.33 & $* * *$ & -1.32 & -5.34 & $* * *$ & 0.17 & ** & 0.12 \\
\hline \multicolumn{11}{|c|}{ Panel A: Money Market Rates } \\
\hline $\mathrm{J} 1 \mathrm{~N}$ & -2.34 & & -4.97 & *** & -2.35 & -12.41 & $* * *$ & 0.15 & ** & 0.06 \\
\hline $\mathrm{J} 1 \mathrm{M}$ & -2.03 & & -10.10 & *** & -2.13 & -10.10 & *** & 0.18 & ** & 0.04 \\
\hline $\mathrm{J} 3 \mathrm{M}$ & -2.15 & & -6.20 & $* * *$ & -1.73 & -6.20 & $* * *$ & 0.21 & $* *$ & 0.05 \\
\hline ICM & -2.84 & * & -13.30 & $* * *$ & -2.48 & -13.43 & $* * *$ & 0.16 & ** & 0.06 \\
\hline \multicolumn{11}{|c|}{ Panel B: Deposit Rates } \\
\hline D1M & -1.99 & & -3.63 & ** & -1.47 & -5.61 & *** & 0.20 & ** & 0.09 \\
\hline D3M & -1.82 & & -3.74 & $* *$ & -1.45 & -8.33 & $* * *$ & 0.21 & $* *$ & 0.10 \\
\hline D6M & -3.15 & & -2.89 & & -1.49 & -5.32 & $* * *$ & 0.21 & $* *$ & 0.10 \\
\hline D1Y & -2.26 & & -2.95 & & -1.29 & -4.47 & $* * *$ & 0.23 & $* * *$ & 0.12 \\
\hline $\mathrm{D} 2 \mathrm{Y}$ & -1.05 & & -8.16 & $* * *$ & -1.33 & -8.29 & $* * *$ & 0.24 & $* * *$ & 0.12 \\
\hline \multicolumn{11}{|c|}{ Panel Lending Rates } \\
\hline CAP & -1.69 & & -2.89 & & -0.96 & -8.34 & $* * *$ & 0.27 & $* * *$ & 0.13 \\
\hline INV & -2.10 & & -4.18 & $* * *$ & -0.95 & -8.59 & $* * *$ & 0.27 & $* * *$ & 0.12 \\
\hline CONS & -2.08 & & -1.88 & & -0.82 & -11.2 & $* * *$ & 0.26 & $* * *$ & 0.22 \\
\hline MNR & -0.17 & & -9.24 & $* * *$ & -0.34 & -9.29 & $* * *$ & 0.27 & $* * *$ & 0.22 \\
\hline MRA & -3.52 & $* * *$ & -6.37 & $* * *$ & -0.84 & -8.35 & $* * *$ & 0.26 & $* * *$ & 0.20 \\
\hline $\mathrm{MRH}$ & -1.21 & & -2.20 & & -0.31 & -8.32 & $* * *$ & 0.29 & $* * *$ & 0.19 \\
\hline $\mathrm{OTH}$ & -2.86 & * & -12.75 & $* * *$ & -3.06 & -12.76 & $* * *$ & 0.13 & $*$ & 0.17 \\
\hline VEH & -3.88 & $* * *$ & -2.95 & & -1.78 & -6.46 & $* * *$ & 0.10 & & 0.10 \\
\hline
\end{tabular}

(Panel B) throughout the sample period. Markup for lending rates ranges from $9 \%$ to $17 \%$, whereas markup for deposit rates, ranges from $1 \%$ to $2 \%{ }^{22}$. On average, the consumer loans rates have higher markup than working capital and investment loans. Liu et al. (2016) argued that the high markup might relate to several factors, including (1) the risky nature of the loans rate, and (2) the competition in the sector. The lenders maintain higher markup as an extra cushion that allows them to pass on less portion of the official rates changes to their customers.

The results show that the change in constant intermediation margin is positive and significant for most of the interest rates, which indicates extensive increase in markups after the change of the benchmark policy rate. The markup for long-term

${ }^{22}$ These are the markup for D6M and D1Y. The markup for other deposit rates is insignificant. 
money market rates has increased by around 3.80\% to $4.25 \%$ during the 7DRR regime, while the markup for short-term and one-year deposit rates has increased by around $4.00 \%$ to $4.85 \%$. However, the increase in the markup for aggregate lending rates only range from $1.76 \%$ to $2.27 \%$.

As for the degree of long-run pass through, we find that all the estimated parameters in Panels A and B are statistically significant at the 1\% level. During the $\mathrm{BI}$ rate regime, the size of long-run pass through to short-term money market rates and the 12-month deposit rate is close to one. Besides, the Wald test results failed to reject the null hypothesis that $H_{0}: \alpha_{1} \alpha_{1}=1$ against the alternative that $H_{1}: \alpha_{1} \neq 1$ at the $1 \%$ level, meaning that there is a complete long-run pass-through from the official rate to the overnight market and the one-year deposit rates. However, the rates on long-term money market and short-term deposit rates adjust more than one-toone to policy rate changes. This suggests that the interest rates were hypersensitive to the change in the BI rates. ${ }^{23}$ In contrast, the pass-through parameters for the two-year deposit rate has a negative sign, which indicates reverse adjustment. The results in Panels $C$ and D show that the long-run pass-through to lending rates of the policy rates were incomplete. The degree of long-run pass-through from the BI rates to working capital and investment loan rates was higher than to consumption loan rate. ${ }^{24}$ Moreover, we only find the expected sign and significance on the longrun pass-through parameters of non-residential and apartment mortgage rates. This result indicates that the other consumption loan products are stickier and less sensitive to policy rate changes.

After the introduction of the new benchmark policy rates, the change in longrun pass-through is negative and significant for long-term money market and short-term deposit rates. This suggests that the transmission from 7DRR to these rates was lower compared to the BI rate. As the magnitude decreases, the passthrough from the policy rate to three to six-month money market rates becomes complete. ${ }^{25}$ On the other hand, the pass-through to short-term deposit rates becomes incomplete. ${ }^{26}$ Thus, the market rates appear to be more closely linked to the policy rate. Similarly, the change of the benchmark rate also reduced the long-run pass-through to lending rates. There are no differences in the response of the overnight money market rates and long-term deposit rates before and after the change of the benchmark policy rates. ${ }^{27}$ Our finding of an incomplete longrun pass-through to the deposit and lending rates are consistent with previous findings for Indonesia (see Yu et al. (2013) and Wibowo and Lazuardi (2016)) and other Asian countries (see Chong et al. (2006), Chong (2010), Wang and Thi (2010) and Zulkhibri (2012)).

\footnotetext{
${ }^{23}$ The Wald test results successfully rejected the null hypothesis of complete pass-through, confirming the over complete long-run pass-through.

${ }^{24}$ Similarly, based on meta analysis, Gregor et al. (2019) also concluded that in most countries the transmission from monetary policy to consumer lending rates appears to be the weakest as compared to corporate lending rates.

25 This is supported by the Wald test result, which failed to reject the null hypothesis of Ho: $\alpha_{1}+\alpha_{3}=1$.

${ }^{26}$ This is supported by the Wald test result, which sucsessfully rejected the null hypothesis of Ho: $\alpha_{1}+\alpha_{3}=1$ at $1 \%$.

27 This is supported by the Wald test result, which failed to reject the null hypothesis of $H_{0}: \alpha_{1}=\alpha_{1}+\alpha_{3}$.
} 


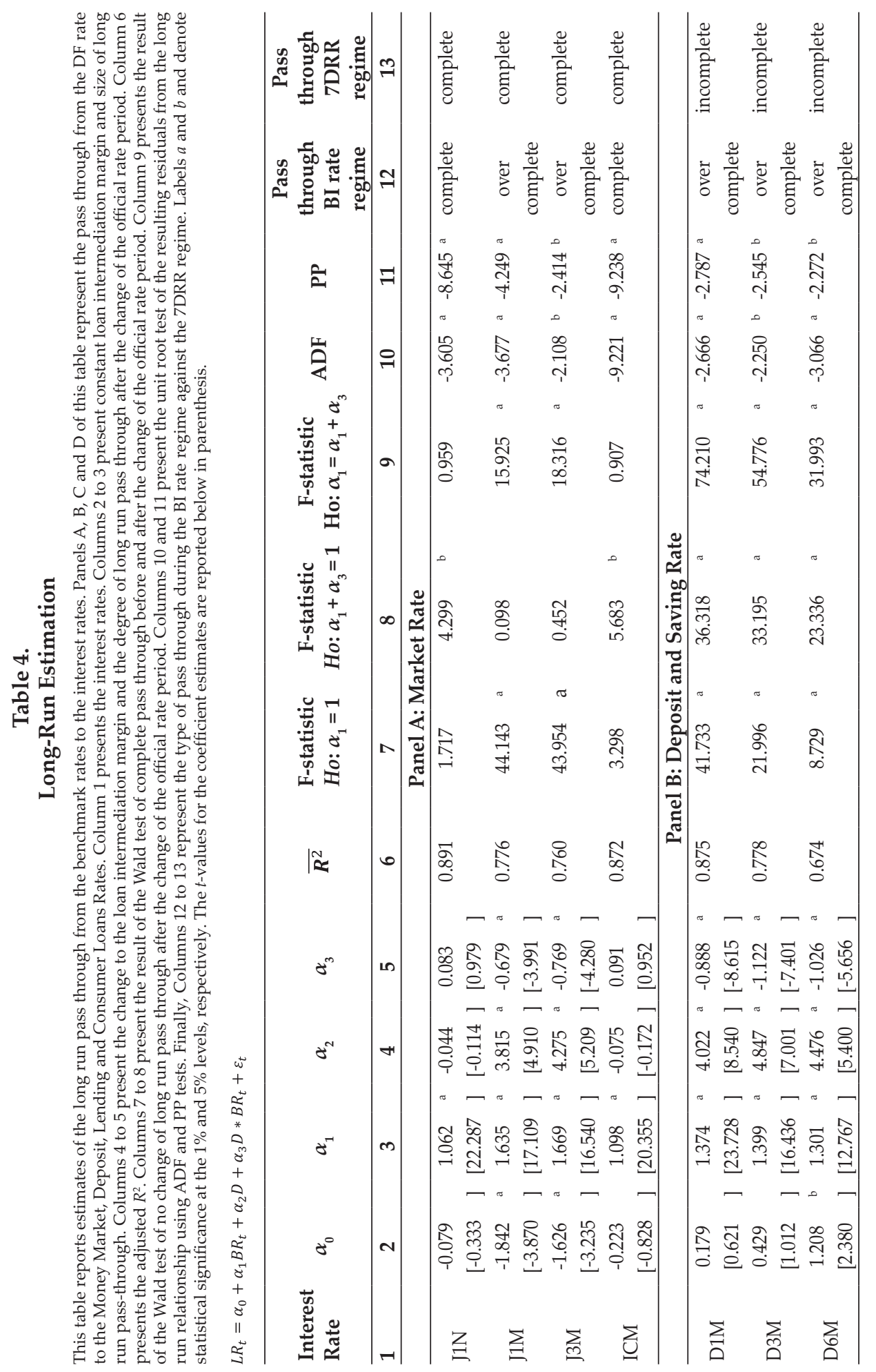




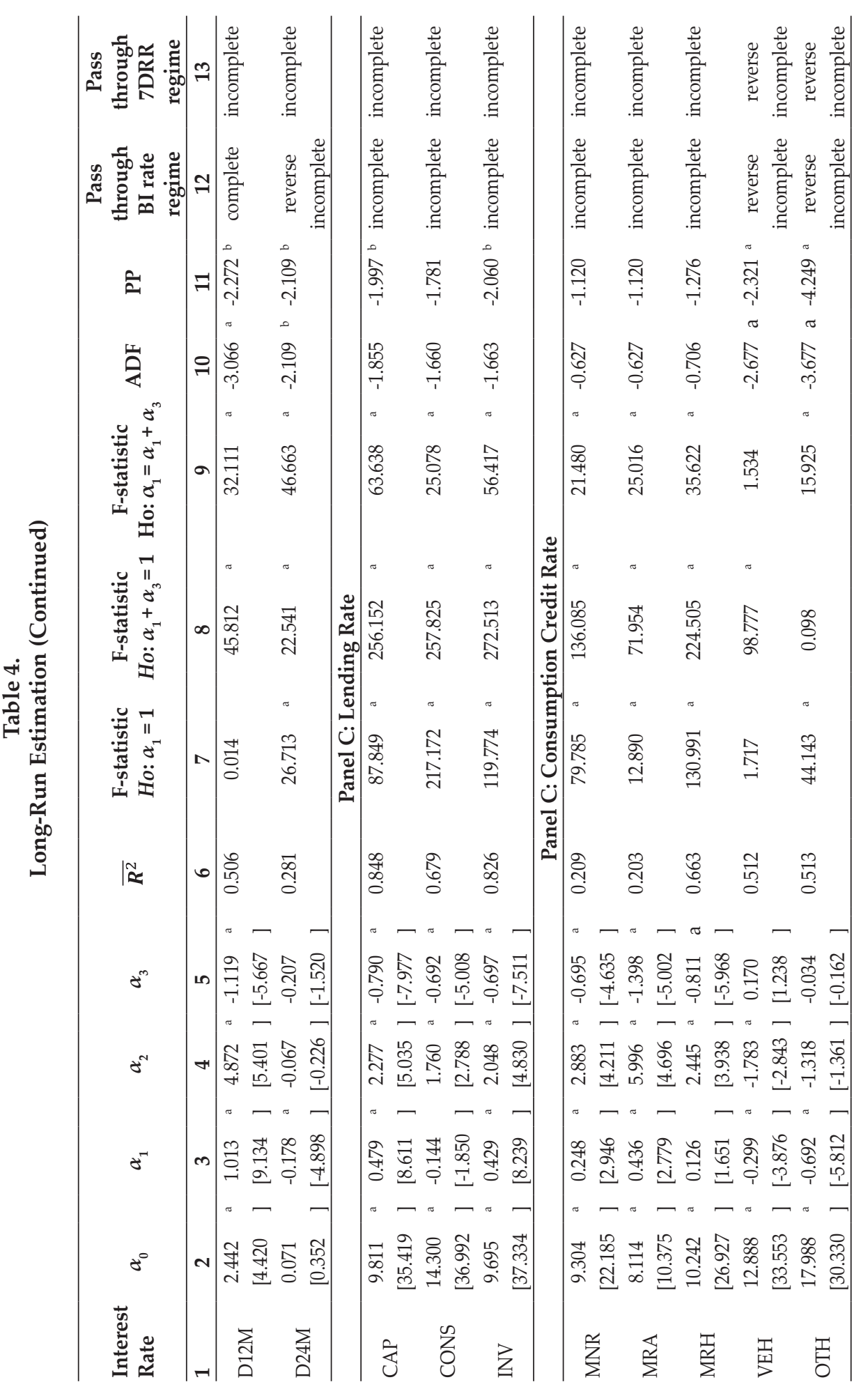


Thus, the change in the benchmark rates has changed the long-run relationship between the interest rates. First, it has increased the markups. Second, it has decreased the size of the long-run pass-through from the official rates to the interest rates. During the 7-day repo rate period, the pass-through to money market rates was complete, suggesting that the money market is fully responsive to monetary policy. However, the deposit and lending rates tend to be stickier, meaning that the introduction of the new benchmark policy rate, by far, has reduced the size of the interest rate response to monetary policy actions.

We also conclude that the consumption loan rates are the most insensitive to the policy rate during both the BI rate and the 7DRR policy regimes. ${ }^{28}$ This finding is in line with the one documented by Prabheesh and Rahman (2019) that credit $\operatorname{card}^{29}$ usage is not responsive to policy rate changes, suggesting the stickiness of the consumer lending rate. Since the residuals obtained from the long-run estimates in the Panels A and B are stationary ${ }^{30}$, we can argue that the policy rate and the interest rate are cointegrated (see, also, Valadkhani and Anwar, 2012). Not surprisingly, the estimated adjusted $R^{2}$ for each of the lending rates resemble their correlation to the benchmark rates. ${ }^{31}$

\section{E. Asymmetric Short-Run Pass-through}

We investigate the short-run dynamics under the asymmetry assumption using Equations (2) and (3), and these results are reported in Tables 5 and 6.

During the BI rate regime, the estimated coefficient of the short-run passthrough from the policy rate to the money market rates is significant. Not surprisingly, we find that the direct pass-through to market rates is complete and increase along with the maturity. However, in Panels B and C, we only find the short-run pass-through to the one-month deposit and investment loan rates. Thus, we may argue that the changes in the BI rate have no direct effect on most of the deposit and lending rates.

Next, we examine the estimated coefficients for each of the error-correction terms to analyze the adjustment asymmetries. For the case of money market rates, we find that the estimated coefficients of the positive disequilibria (i.e. $\varphi_{4}^{+}$) (in Table 4) and also for the large positive disequilibria (i.e. $\varphi_{6}{ }^{{ }^{+}}$) (in Table 5) for short-term market rates are statistically significant at the $1 \%$ level. However, the estimated coefficients capturing the negative disequilibria, (i.e., $\varphi_{4}^{-}$), the large negative disequilibria (i.e. $\varphi_{6}^{L-}$ ), and the relatively small positive/negative deviations from the long-run path (i.e $\varphi_{6}^{S}$ ) are statistically insignificant, except for overnight interbank rates.

\footnotetext{
${ }^{28}$ Similarly, Rocha (2012) found no cointegration for the personal sector lending rates in Portugal.

${ }^{29}$ Credit card is part of the other loan products.

30 The ADF and PP test results are reported in columns 11 and 12. The ADF test results in Panels A and B range from -2.1 (significant at $5 \%$ ) to -9.2 (significant at $1 \%$ ).

${ }^{31}$ For example, the correlation between the DF rate and the money market rates are the strongest (around 0.91 and 0.93), and the adjusted $R^{2}$ values are also the highest (i.e. 0.76 to 0.89 ). Similarly, the adjusted $R^{2}$ value for consumer loan rates, which have the weakest correlation to policy rates, is also the lowest (0.20 to 0.66$)$.
} 


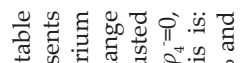
๘

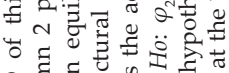

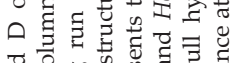
द्व

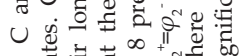

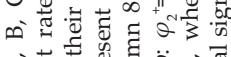

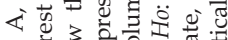

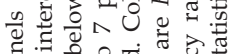

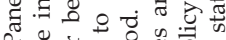
‡

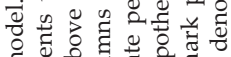

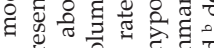
$\cong \overline{2}$

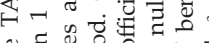
‡ द्व

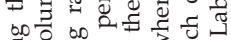
च

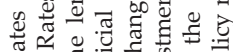

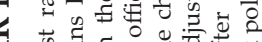

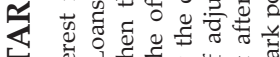

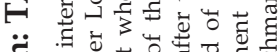

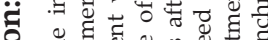
Ð

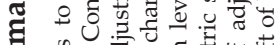

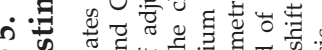
o त $\Xi$.

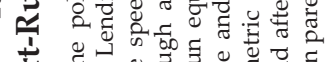

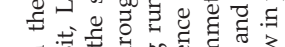

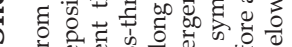

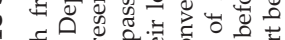

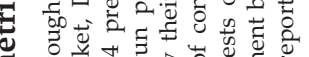

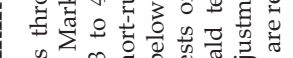
क क क क ₹

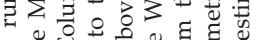

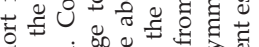

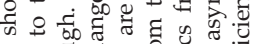

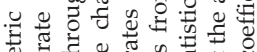

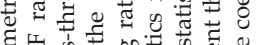

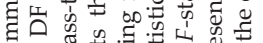

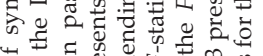

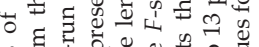

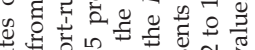

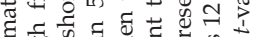
के का

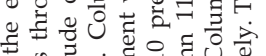
क

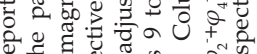

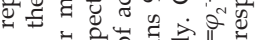

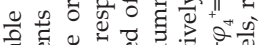

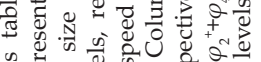

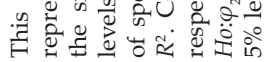

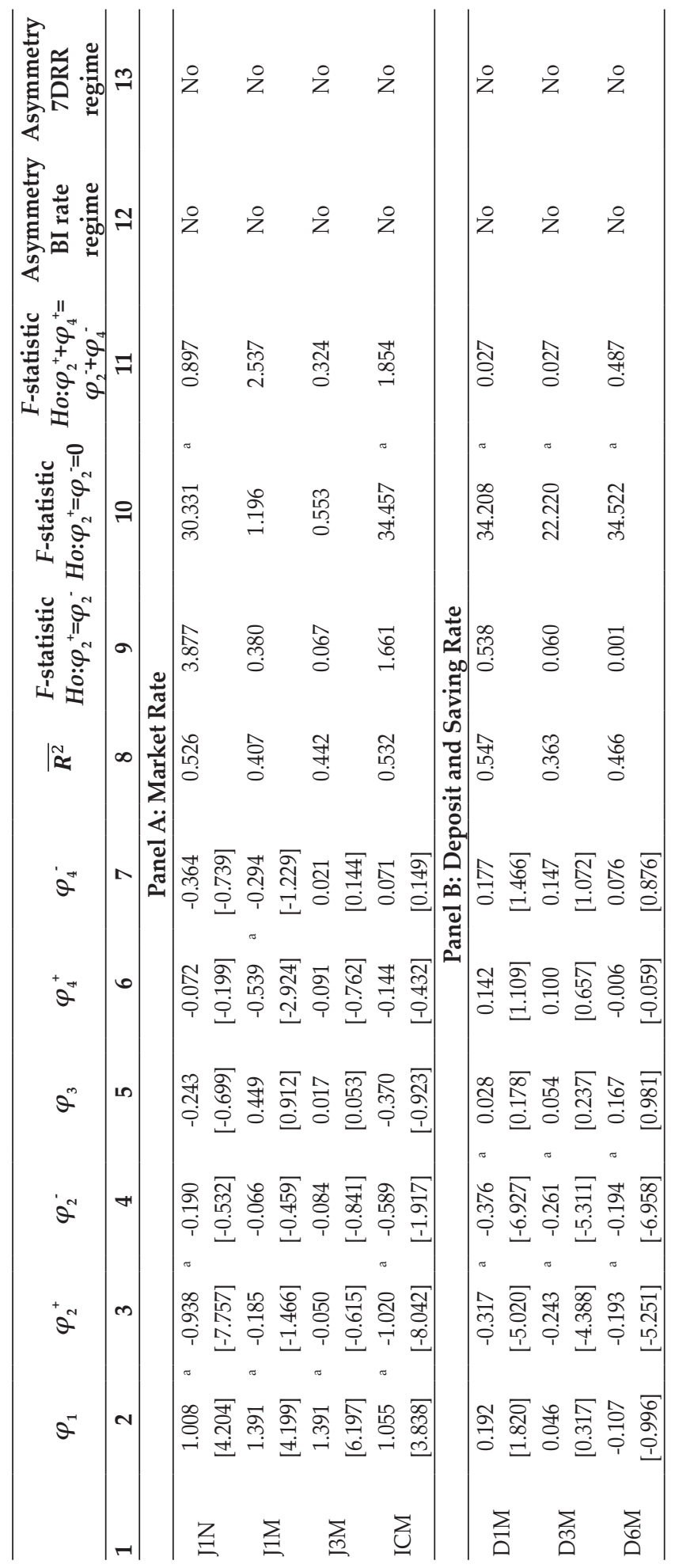




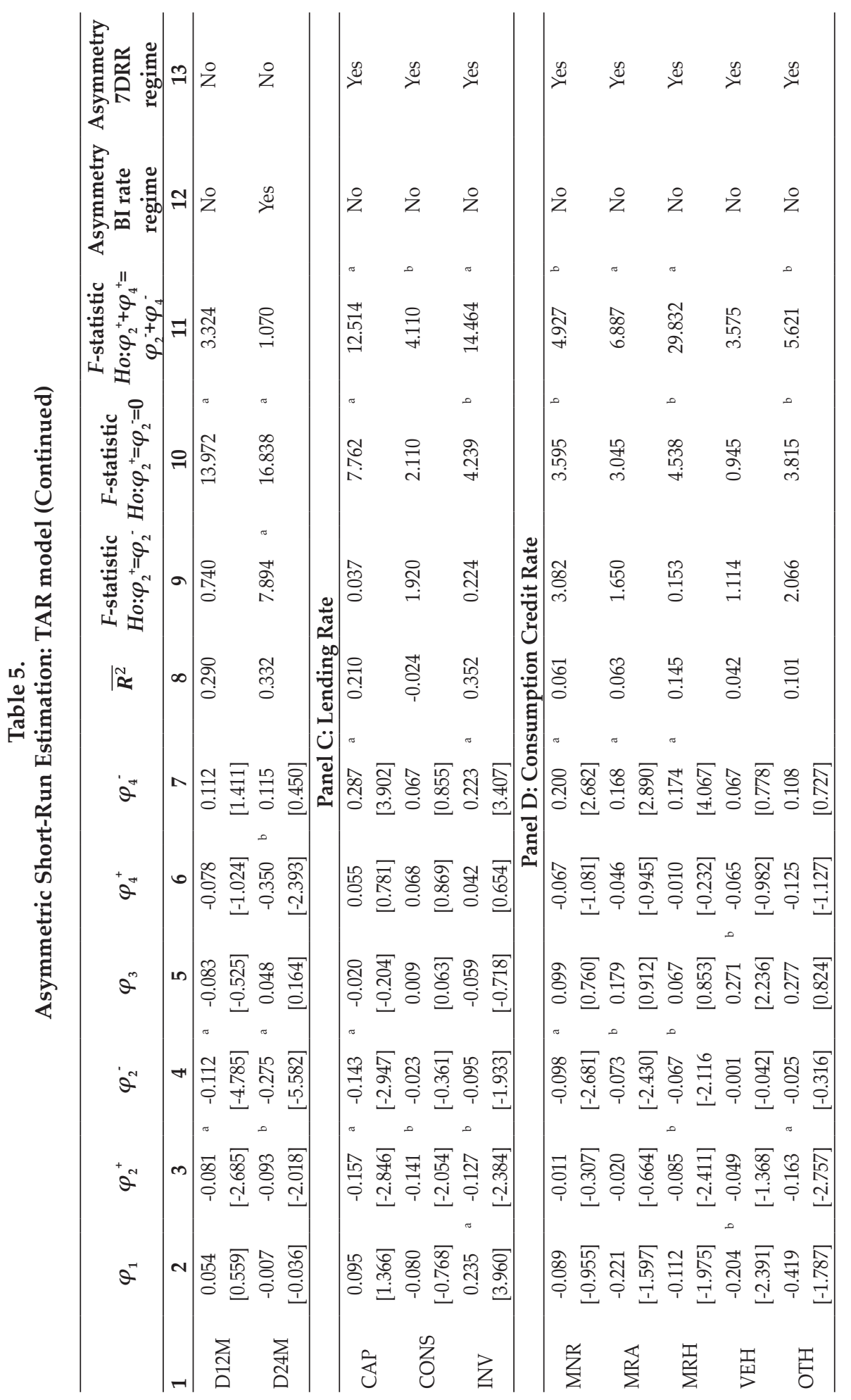




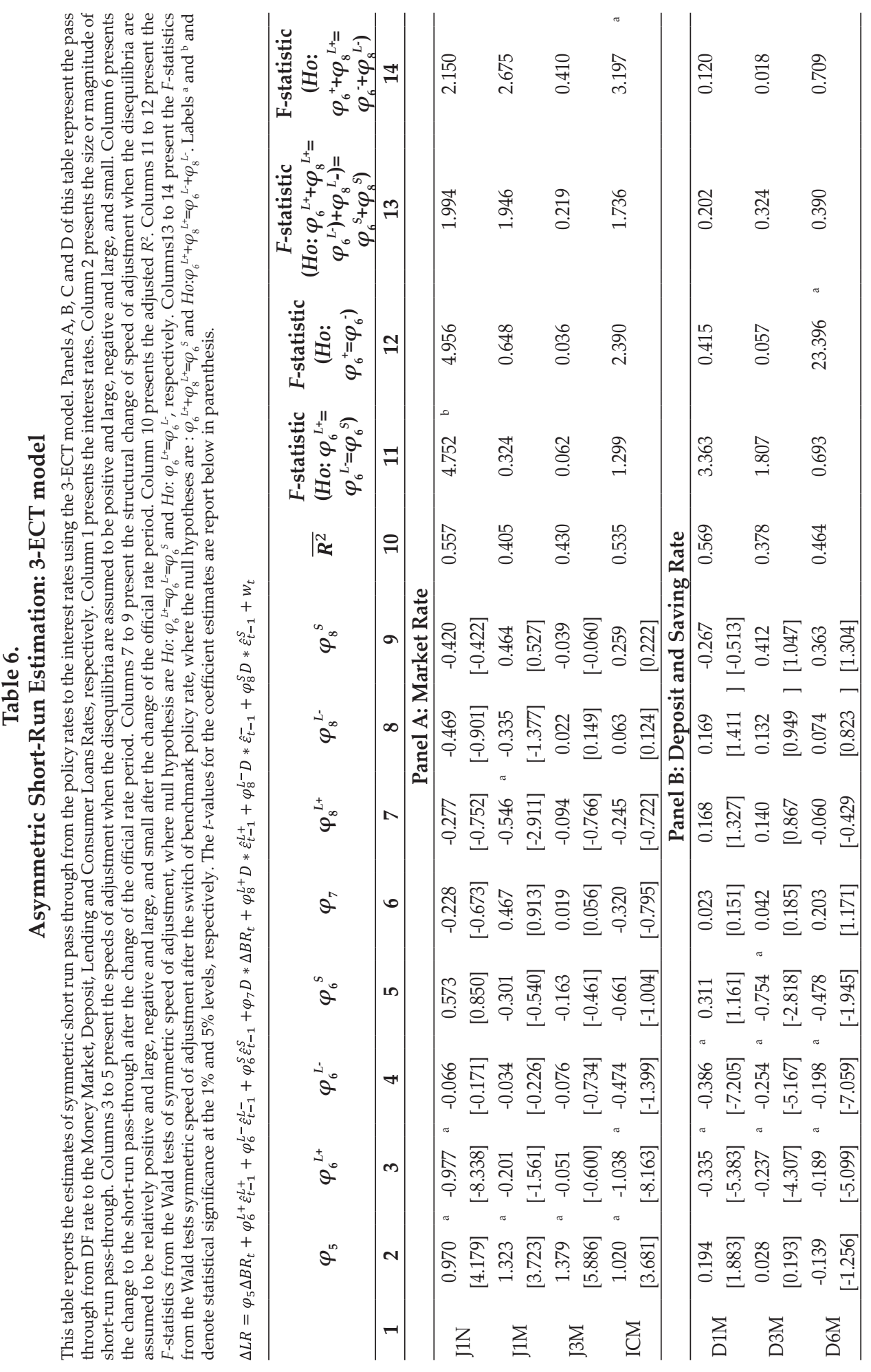




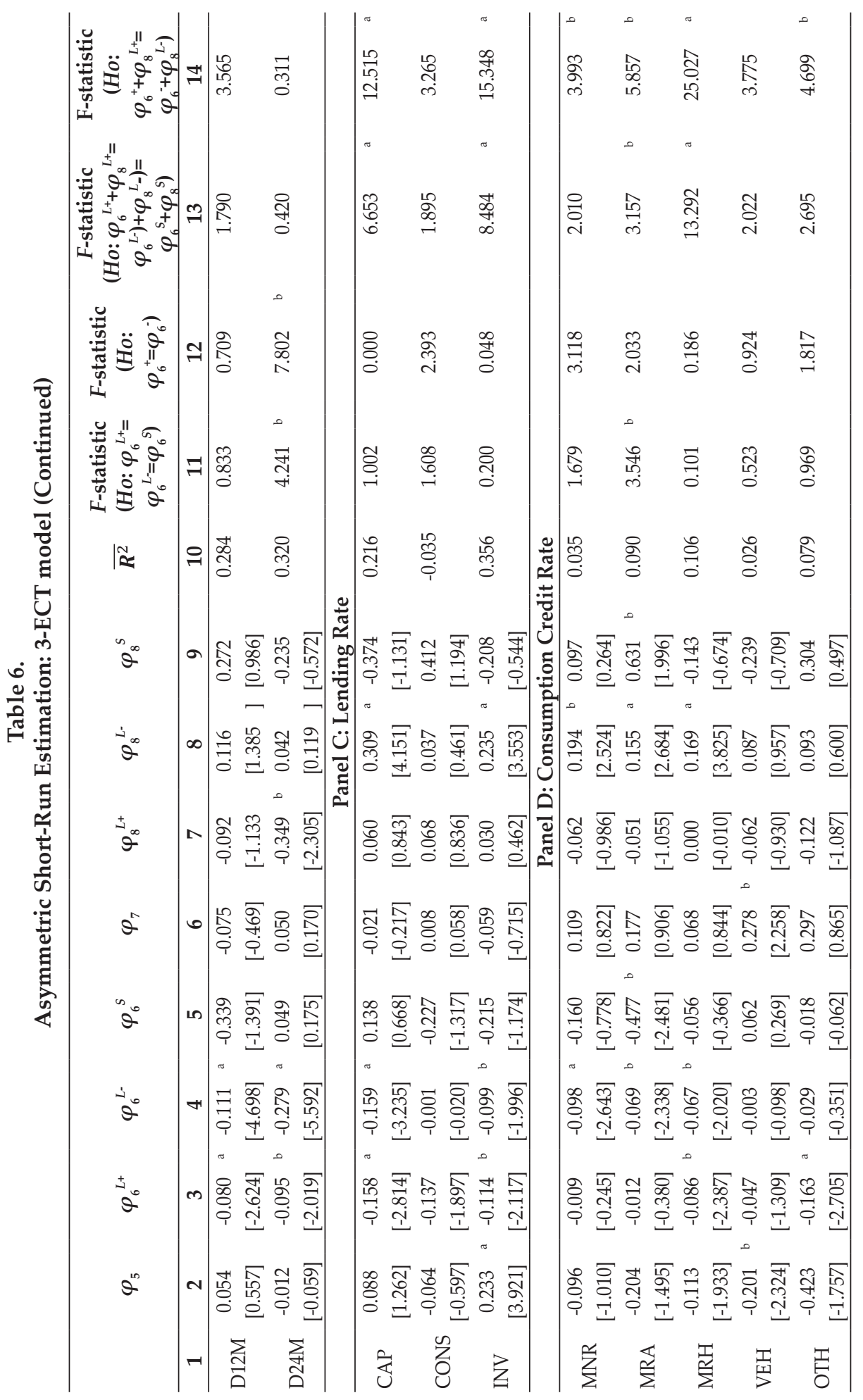


Thus, we may conclude that when actual market rates were distinctly higher than the equilibrium, the banks quickly amended the prevailing gap by lowering their interest rates. For instance, as the policy rate dropped, the overnight JIBOR and the interbank call rates quickly adjusted at the speed of $0.94 \%$ and $1.02 \%$ per month, respectively. These rates, however, are not corrected when they were distinctly below the equilibrium (when the policy rate increased). Although there is an indication that short-term market rates tend to be rigid upward, the Wald test failed to reject the null hypothesis of symmetric adjustments between positive and negative disequilibrium (i.e. under $H o: \varphi_{2}{ }^{+}=\varphi_{2}{ }^{-}$) and between large and small disequilibrium (i.e. under $H o: \varphi_{2}{ }^{{ }^{+}}=\varphi_{2}{ }^{L-}=\varphi_{2}{ }^{S}$ ). In addition, we find that the change to short-run pass-through and speeds of adjustments after the change in benchmark rates are insignificant. Unfortunately, we are unable to find the short-run passthrough from the official rate to the longer-term market rates (one-month and three-month JIBOR).

In Panel B, there is not much difference in the speeds of adjustment between the positive and negative disequilibria for one-year and short-term deposit rates. Additionally, the Wald test result also failed to reject the null hypothesis of symmetric adjustment for large and small disequilibrium conditions. Thus, we conclude that most short-term deposit rates respond to the change in the official rates symmetrically, in terms of direction and magnitude. However, we find that long-term deposit rates are more responsive to the official rate hikes than cuts. For example, whenever the actual two-year deposit rates were distinctly below their equilibrium, the banks quickly amend the gap by raising the rates by $0.28 \%$ per month. In contrast, when the official rates were cut, they corrected the gap by the speed of $0.09 \%$ per month. In addition, the banks tend not to respond to small disequilibrium. The indication of downward rigidity of the long-term deposit rates were supported by the results of Wald tests. Interestingly, after the launch of the new benchmark rates, there was a significant increase in the adjustment speed to positive disequilibrium. Finally, the two-year deposit rate responds to changes in 7DRR symmetrically.

From the results in Panels $C$ and D, we find that most lending rates adjust symmetrically to changes in the BI rate. However, the change in the adjustment speed to negative disequilibrium after the introduction of new benchmark rates is positive and significant for working capital loan and investment loan rates, suggesting that adjustment to an increase in the official rate becomes slower than to a decrease. As the 7DRR drop, the lenders reduce the working capital and investment loans at the speeds of 0.158 and 0.114 per month, respectively. Conversely, such correction does not occur when the 7DRR rise, which means that lenders temporarily continue charging below the equilibrium rates. Our finding is in contrast to Yu et al. (2013), who discovered an asymmetric long-run passthrough to investment loan rates in Indonesia, but not in the adjustment speeds.

Similarly, the speed of adjustment of the mortgage rates to policy rate changes has been reduced in the 7DRR regime. Accordingly, we conclude that, lending rates are more sensitive to the policy rate cuts than to the policy rate hikes, which suggests downward asymmetry. The indication of asymmetric adjustments to positive and negative changes in the policy rates has been confirmed by the Wald tests under Ho: $\varphi_{2}^{+}+\varphi_{4}{ }^{+}=\varphi_{2}^{-}+\varphi_{4}^{-}$. Moreover, lenders did not react to a variety 
of reasonably small disequilibria, which is confirmed by the Wald tests under Ho: $\varphi_{2}{ }^{{ }^{+}+}+\varphi_{4}{ }^{{ }^{+}+}=\varphi_{2}{ }^{L-}+\varphi_{4}{ }^{L-}=\varphi_{2}{ }^{S}+\varphi_{4}{ }^{S}$. Our findings are opposite to Valadkhani and Worthington (2014), who found mortgage rates in Australia respond to large negative disequilibria faster than to large positive and small disequilibria.

This type of asymmetry leads to upward rigidity, as lenders demonstrate more rigidity in passing on the positive shocks in the policy rates onto their lending rates. There are two theories that may justify this outcome: the customer-reaction hypothesis $^{32}$ and the asymmetric information hypothesis ${ }^{33}$. According to the first theory, lenders are more aware of their customers because of competition in the loan market. However, previous studies suggested that there is low competition in the Indonesian banking industry (Widyastuti and Armanto, 2013; Mulyaningsih et al., 2015). ${ }^{34}$ Thus, the second theory offers more promising explanation that lenders are reluctant to raise their lending rates upward in order to avoid risky borrowers. Juhro and Goeltom (2013) argued that the rigidity of lending rates in Indonesia has been induced by the cost of funds and risk premia that tend to rise.

\section{F. Comparison to Empirical Evidence in Other Countries}

Table 7 shows that the existing literature is generally inconclusive about passthrough from official rates or money market rates (as the benchmark rates) to lending rates. Further, there are some notable differences in the Indonesian case compared to other countries.

First, it is easily detectable that the constant loan intermediation margin in Indonesia is considerably the highest, indicating higher markup (Falianty and Listiyanto, 2013). Moreover, the markup has increased during the new policy rate regime. The higher markup provides extra cushion to anticipate funding cost pressure from the policy rate changes to the customers (Liu et al., 2016).

Second, with respect to the magnitude of the long-run pass-through, lenders in Indonesia appear to be less sensitive to the benchmark rate changes given the relatively smaller long-run pass-through than other countries. Our estimated coefficient of the long-run pass-through of the lending rates in Indonesia is close to those estimated for Malaysia (Zulkhibri, 2012) and Singapore (Chong et al., 2006). However, it differs from an earlier study on Indonesia, which reported a higher long-run pass-through of the aggregate consumption lending rates (Wibowo and Lazuardi, 2016). Third, with regards to the asymmetric adjustment speed, we find upward rigidity of the working capital and investment loan rates, which agrees with lending rates in Singapore, Malaysia, South Africa, and the US (Chong et al., 2006; Zulkhibri, 2012; Matemilola et al., 2014; Payne, 2007).

\footnotetext{
${ }^{32}$ For the case of upward interest rate rigidity, Gambacorta and Iannotti (2007) offer the customerreaction hypothesis. It states that, in a very competitive market, there is potential positive asymmetry of lending rates. In such an environment, lenders are less responsive to the increase of the policy rate since customers react negatively when interest rates rise.

${ }^{33}$ Another possible explanation of the upward interest rate rigidity is the adverse selection and moral hazard problems based on an asymmetric information hypothesis from Stiglitz and Weiss (1981). In order to avoid riskier borrower (adverse selection) and/or riskier project (moral hazard), lenders are unwilling to increase their lending rates over a short period. Thus, they might anticipate the rise in funding costs, or in our case the increase of policy rates, by rationing the amount of credit supply.

${ }^{34}$ First, foreign banks appear to be more competitive than local banks. Second, big banks are less competitive than medium and small banks.
} 


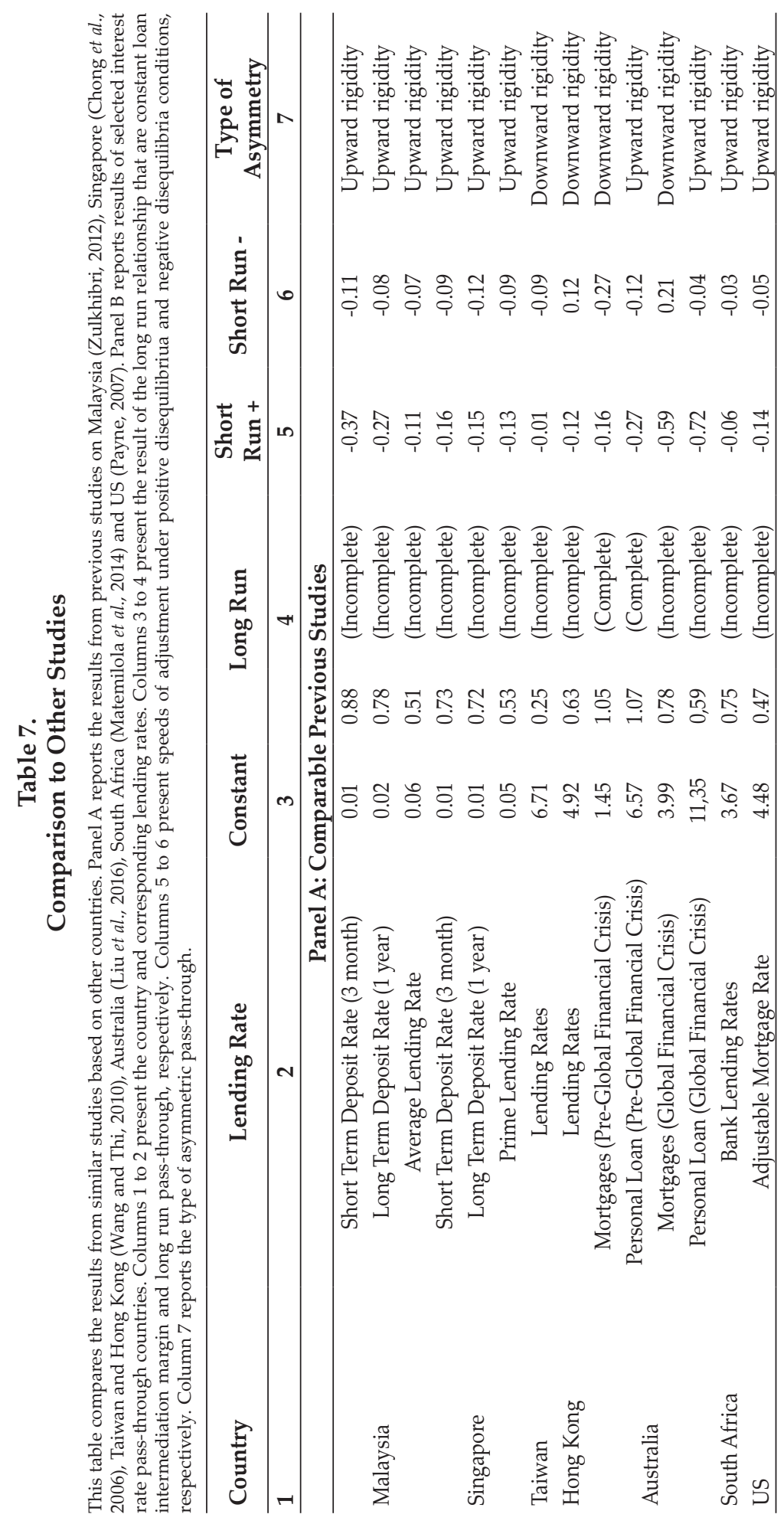




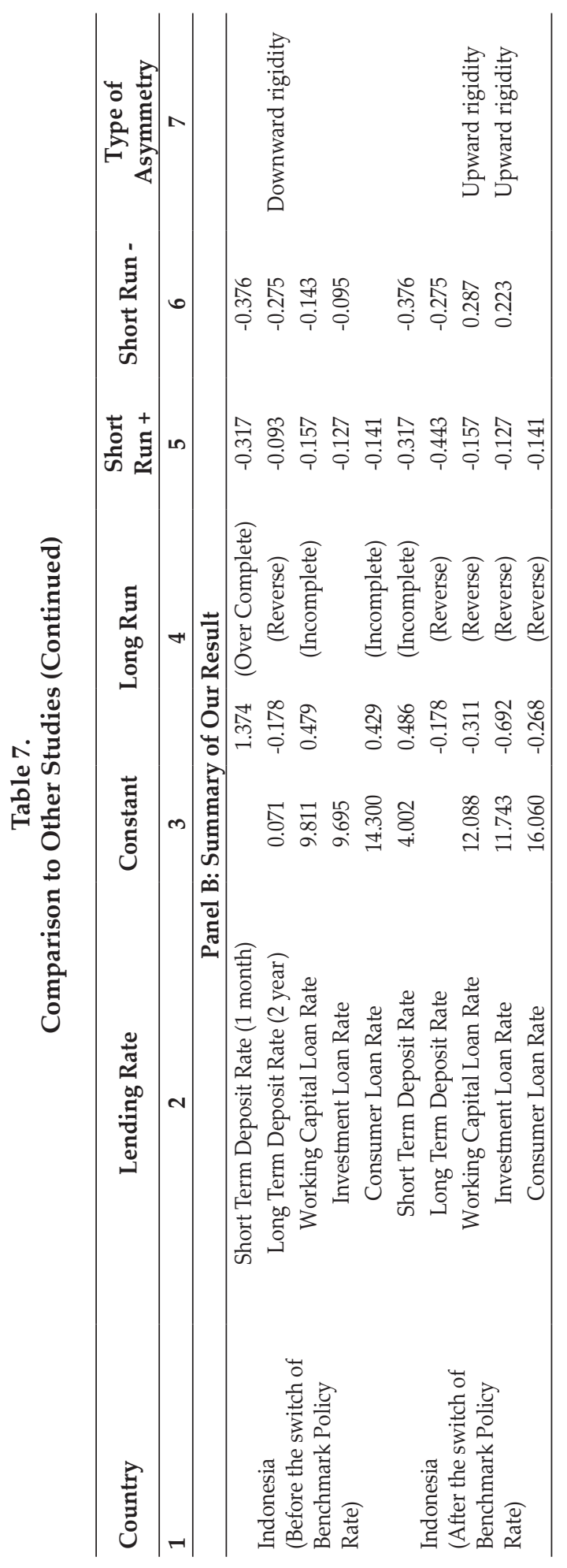




\section{CONCLUSION}

The Bank Indonesia switched its policy rate from the BI rate to the 7-day repo rate in order to improve the efficacy of its monetary policy action. In this study, we provide evidence regarding the effect of the new benchmark policy rate on the interest rate pass-through transmission channel. In particular, we investigate: (1) the changes in the pricing combination, which consists of markup and passthrough, within the two regimes (i.e. the BI rate and the 7-day repo rate regimes); (2) the degree and changes, in both the long-run and short-run, in the pass-through from the policy rates to the interest rates; and (3) the asymmetry and changes in interest rate adjustment speeds in terms of direction and size of policy rate changes.

We find that monetary policy actions have a diverse impact on the money market and retail banks' interest rates. The long-term money market and the short-term deposit rates are highly sensitive and characterized by a low markup and complete pass-through. In contrast, lending rates have a higher markup and a lower degree of pass-through. There are positive changes to the markup and negative changes to the long-run pass-through after the shift in the benchmark policy rate. For the case of money market rates, there is an improvement from complete to one-to-one pass-through following the shift in the benchmark policy rate. However, the pass-through to deposit and lending rates becomes incomplete. Similarly, the short-run analysis shows that monetary policy action has no direct effect on the deposit and lending rates, indicating that retail bank interest rates are less responsive to changes in the policy rate. More importantly, the effect of the monetary policy action on the economy is smaller because the change in the benchmark rate has decreased the size of the interest rate sensitivity. This implies that monetary policy will take a longer time (or larger changes in the monetary policy instruments are required) to produce significant effects on aggregate demand and eventually prices.

Furthermore, for most of the cases, the interest rate adjustments to monetary easing and tightening are symmetric in terms of direction and size of deviation from the equilibrium. However, during the new policy rate regime, the adjustment speed of the working capital and investment loan rates to a large policy rate hike has been reduced, meaning that the lending rates tend to be more responsive to monetary policy easing than to tightening. The asymmetric pass-through may be related to market conditions. First, lending rates are the stickiest in the consumer loans market, which mostly contributes to the average growth of the loans market. This may be attributed to consumer loan products being riskier than other loans. Because of this, central bankers may not look forward to influencing the pricing of consumer loans as effectively as other segments of the loans market. Second, working capital and investment loans, which are less risky and have a moderate term, are found to be rigid upward, meaning that lenders are reluctant to raise loan rates significantly over a short period, which benefits the borrowers. Monetary policy easing will have more impact on borrowers than monetary policy contraction. Since falling policy rates cause lending rates to also fall, monetary policy easing will eventually increase the borrowers' purchasing power, boosting production capacity and economic growth. 


\section{REFERENCES}

Andries, N., \& Billon, S. (2016). Retail Bank Interest Rate Pass-Through in the Euro Area: an Empirical Survey. Economic Systems, 40, 170-194.

Apergis, N., \& Cooray, A. (2015). Asymmetric Interest Rate Pass-Through in the U.S., the U.K. and Australia: New Evidence from Selected Individual Banks. Journal of Macroeconomics, 45, 155-172.

Bank Indonesia. (2014). Monetary Policy Review [Economy, Monetary and Finance] January 2014. Jakarta: Monetary and Economic Policy Department, Bank Indonesia.

Bank Indonesia. (2018). Monetary Policy Review [Economy, Monetary and Finance] January 2018. Jakarta: Monetary and Economic Policy Department, Bank Indonesia.

Bank Indonesia. (2020). Indonesian Financial Statistics. Jakarta: Bank Indonesia.

Becker, R., Osborn, D. R., \& Yildirim, D. (2012). A Threshold Cointegration Analysis of Interest Rate Pass-Through to UK Mortgage Rates. Economic Modelling, 29, 2504-2513.

Boswijk, H. P. (1994). Testing for an Unstable Root in Conditional and Structural Error Correction Models. Journal of Econometrics, 63, 37-60.

Cecchin, I. (2011). Mortgage Rate Pass-Through in Switzerland. Zurich: Swiss National Bank Working Paper.

Chong, B. (2010). Interest Rate Deregulation: Monetary Policy Efficacy and Rate Rigidity. Journal of Banking and Finance, 34, 1299-1307.

Chong, B., Liu, M., \& Shrestha, K. (2006). Monetary Transmission Via the Administered Interest Rates Channel. Journal of Banking \& Finance, 30, 14671484.

De Bondt, G. J. (2005). Interest Rate Pass-Through: Empirical Results for the Euro Area. German Economic Review, 6, 37-78.

Devpura, N., \& Narayan, P. K. (2020). Hourly Oil Price Volatility: The Role of COVID-19. Energy Research Letters, 1.

Enders, W., \& Siklos, P. L. (2001). Cointegration and Threshold Adjustment. Journal of Business \& Economic Statistics, 19, 166-176. https://doi.org/10.46557/001c.13683.

Falianty, T. A., \& Listiyanto, E. (2013). Analisis Kekakuan dan Faktor-faktor yang Mempengaruhi Tingkat Suku Bunga Perbankan di Indonesia. Jurnal Kebijakan Ekonomi, 8, 26-36.

Frost, D., \& Bowden, R. (1999). An Asymmetry Generator for Error-Correction Mechanisms, with Application to Bank Mortgage-Rate Dynamics. Journal of Business \& Economic Statistics, 17, 253-263.

Gambacorta, L., \& Iannotti, S. (2007). Are There Asymmetries in the Response of Bank Interest Rates to Monetary Shocks? Applied Economics, 39, 2503-2517.

Gregor, J., Melecký, A., \& Melecký, M. (2019). Interest Rate Pass-Through: A MetaAnalysis of the Literature (Worldbank Group Policy Research Working Paper No. 8713). World Bank.

Haan, L., \& Sterken, E. (2011). Bank-Specific Daily Interest Rate Adjustment. Journal of Financial Service Research, 145-159.

Haroon, O., \& Rizvi, S. A. (2020). COVID-19: Media Coverage and Financial Markets Behavior-A Sectoral Inquiry. Journal of Behavioral and Experimental Finance, 27. 
Hofmann, B., \& Mizen, P. (2004). Interest Rate Pass-trough and Monetary Transmission: Evidence from Individual Financial Institutions' Retail Rates. Economica, 71, 99-123.

Indonesian Financial Services Authority. (2020). Indonesian Banking Statistics. Jakarta: Indonesian Financial Services Authority.

Iyke, B. (2017a). On the Term Structure of South African Interest Rates: Cointegration and Threshold Adjustment. International Journal of Sustainable Economy, 9, 300.

Iyke, B. (2017b). Asymmetries in Yield Curves: Some Empirical Evidence from Ghana. MPRA Paper, 79155.

Iyke, B. (2020a). COVID-19: The Reaction of US Oil and Gas Producers to the Pandemic. Energy Research Letters, 1.

Iyke, B. (2020b). The Disease Outbreak Channel of Exchange Rate Return Predictability: Evidence from COVID-19. Emerging Markets Finance and Trade, 56, 2277-2297. https://doi.org/10.46557/001c.13912.

Juhro, S., \& Goeltom, M. (2013). The Monetary Regime in Indonesia. MacroFinancial Linkages in Pacific Region, Akira Kohsaka (Ed.), Routledge, February 2015.

Juhro, S., \& Iyke, B. (2019a). Monetary Policy and Financial Conditions in Indonesia. Bulletin of Monetary Economics and Banking, 21, 283-302.

Juhro, S., \& Iyke, B. (2019b). Forecasting Indonesian Inflation within an Inflationtargeting Framework: Do Large-Scale Models Pay Off? Bulletin of Monetary Economics and Banking, 22, 423-436.

Juhro, S., \& Iyke, B. (2020). Consumer Confidence and Consumption Expenditure in Indonesia. Economic Modelling, 89, 367-377.

Kremers, J. J., Ericsson, N. R., \& Dolado, J. J. (1992). The Power of Cointegration Tests. Oxford Bulletin of Economics and Statistics, 54, 325-248.

Lim, G. (2001). Bank Interest Rate Adjustments: Are They Asymmetric? The Economic Record, 77, 135-147.

Liu, M., Margaritis, D., \& Qiao, Z. (2016). The Global Financial Crisis and Retail Interest Rate Pass-Through in Australia. Review of Pacific Basin Financial Markets and Policies, 19, 1650026.

Liu, M., Margaritis, D., \& Tourani-Rad, A. (2008). Monetary Policy Transparency and Pass-Through of Retail Interest Rates. Journal of Banking and Finance, 32, 501-511.

Månsson, K., Shukur, G., \& Sjölander, P. (2013). Asymmetric Quantile Analysis of the Swedish Mortgage Price Discovery Process. Applied Economics, 45, 30883101.

Matemilola, B. T., Bany-Ariffin, A. N., \& Muhtar, F. E. (2014). Impact of Monetary Policy on Bank Lending Rate in South Africa. Borsa Istanbul Review, 1-7.

Mishra, A., Rath, B., \& Dash, A. (2020). Does the Indian Financial Market Nosedive Because of the COVID-19 Outbreak, in Comparison to After Demonetisation and the GST? Emerging Markets Finance and Trade, 56, 2162-2180.

Mulyaningsih, T., Daly, A., \& Miranti, R. (2015). Foreign Participation and Banking Competition: Evidence from the Indonesian Banking Industry. Journal of Financial Stability, 19, 70-82.

Payne, J. E. (2006). More on the Monetary Transmission Mechanism: Mortgage Rates and the Federal Funds Rate. Journal of Post Keynesian Economics, 29, 247257. 
Payne, J. E. (2007). Interest Rate Pass Through and Asymmetries in Adjustable Rate Mortgages. Applied Financial Economics, 17, 1369-1376.

Peltzman, S. (2000). Prices Rise Faster Than They Rall. Journal of Political Economy, 108, 466-502.

Phan, D., \& Narayan, P. (2020). Country Responses and the Reaction of the Stock Market to COVID-19-a Preliminary Exposition. Emerging Markets Finance and Trade, 56, 2138-2150.

Pontines, V., \& Siregar, R. Y. (2017). Non-core Liabilities and Monetary Policy Transmission in Indonesia during the Post-2007 Global Financial Crisis (Working Papers No 78). Centre for Applied Macroeconomic Analysis, Crawford School of Public Policy, The Australian National University.

Prabheesh, K. P., \& Rahman, R. E. (2019). Monetary Policy Transmission and Credit Cards: Evidence from Indonesia. Bulletin of Monetary Economics and Banking, 22, 137-162.

Prabheesh, K., Padhan, R., \& Garg, B. (2020). COVID-19 and the Oil Price-Stock Market Nexus: Evidence from Net Oil-Importing Countries. Energy Research Letter, 1, 13745.

Rocha, M. D. (2012). Interest Rate Pass-Through in Portugal: Interactions, Asymmetries and Heterogeneities. Journal of Policy Modeling, 34, 64-80. https://doi.org/10.46557/001c.13745.

Rousseas, S. (1985). A Markup Theory of Bank Loan Rates. Journal of Post Keynesian Economics, 8, 135-144.

Sjölander, P. (2013). A Ridge Bootstrap Method for Analyzing APT Effects on the Mortgage Loan Market. Economic Modelling, 30, 844-855.

Sjölander, P., Shukur, G., Månsson, K., \& Kekezi, O. (2015). The Efficiency of the Scandinavian Banking Sector - a Wavelet Quantile Regression Analysis. Applied Economics, 47, 5378-5389.

Stiglitz, J., \& Weiss, A. (1981). Credit Rationing in Markets with Imperfect Information. American Economic Review, 71, 393-410.

Tai, P. N., Sek, S. K., \& Har, W. M. (2012). Interest Rate Pass-Through and Monetary Transmission in Asia. International Journal of Economics and Finance, 4, 163-174.

Toolsema, L., \& Jacobs, J. P. (2007). Why Do Prices Rise Faster Than They Fall? With an Application to Mortgage Rates. Managerial Decision Economics, 28, 701-712.

Valadkhani, A., \& Anwar, S. (2012). Interest Rate Pass-Through and the Asymmetric Relationship between the Cash Rate and the Mortgage Rate. The Economic Record, 88, 341-350.

Valadkhani, A., \& Worthington, A. (2014). Asymmetric Behavior of Australia's Big-4 Banks in the Mortgage Market. Economic Modelling, 43, 57-65.

Vidya, C. T., \& Prabheesh, K. (2020). Implications of COVID-19 Pandemic on the Global Trade Networks. Emerging Markets Finance and Trade, 56, 2408-2421.

Wang, K., \& Thi, T. N. (2010). Asymmetric Pass-Through and Risk of Interest Rate: an Empirical Exploration of Taiwan and Hong Kong. Applied Economics, 42, 659-670.

Warjiyo, P., \& Juhro, S. (2019). Central Bank Policy: Theory and Practice. Jakarta: Emerald Publishing Limited. 
Wibowo, B., \& Lazuardi, E. (2016). Empirical Evidence of Monetary Policy Transmission Mechanism: Indonesia Banking Sector Interest Rate Passthrough. Jurnal Ekonomi dan Pembangunan Indonesia, 16, 187-204.

Widyastuti, R. S., \& Armanto, B. (2013). Banking Industry Competition in Indonesia. Bulletin of Monetary, Economics and Banking, 15, 401-433.

Yu, B., Chun, S. E., \& Kim, J. (2013). Some Evidence on the Asymmetry of Interest Rate Pass-Through in Asian Economies. Korea and the World Economy, 14, 207233.

Zulkhibri, M. (2012). Policy Rate Pass-Through and the Adjustment of Retail Interest Rates: Empirical evidence from Malaysian Financial Institutions. Journal of Asian Economics, 23, 409-422. 
This page is intentionally left blank 